Supporting Information

\title{
Indium Tin-doped Oxide (ITO) as a High Activity Water Oxidation Photoanode
}

Matthew V. Sheridan, Jeffrey R. McLachlan, Johan R. González-Moya, Nicole D. Cortés-Medina, Christopher J. Dares*

Florida International University, Department of Chemistry and Biochemistry, 11200 SW 8th St. Miami, Florida 33199, United States

email: cdares@fiu.edu

Experimental Section.

All chemicals and reagents were purchased from Fisher Scientific and used as received. Electrochemical experiments (cyclic voltammetry (CV), linear sweep voltammetry (LSV), opencircuit potential (OCP)) were performed using a $\mathrm{CH}$ Instruments $650 \mathrm{~B}$ potentiostat or $760 \mathrm{E}$ bipotentiostat. A saturated calomel electrode (SCE) was used as the reference electrode for aqueous studies, and a graphite rod or platinum wire were used as the counter electrode. A custom built two-compartment cell comprised of a $1 \mathrm{~cm}$ path length borosilicate cuvette connected to a length of square borosilicate glass through a fine glass frit was used for all electrochemical, spectroscopic, and spectroelectrochemical studies.

NanolTO slides were from $15 \mathrm{wt} \%$ suspensions of nanoparticle ITO (US Research Nanomaterials, Inc.) by doctor blading on to planar FTO glass slides and annealing at the desired temperature for $10 \mathrm{~h}$. The nanolTO slides absorb strongly in the UV with a yellowish hue (Figure S2). NanolTO slides prepared at $250^{\circ} \mathrm{C}$ had a reddish-brown color after annealing that was greatly diminished after CV and photolysis experiments (Figure S3). A shift in the mid-infrared absorption band was also observed at nanolTO annealed above $250{ }^{\circ} \mathrm{C}$ which has been described previously and compared to the same absorption region for $\mathrm{TiO}_{2}$ (Figure S4). ${ }^{1} \mathrm{UV}$-visible spectra of ITO films were collected using an Agilent 8454 spectrophotometer.

Scanning Electron Microscope images were collected on a Hitachi S-4700 SEM. X-ray photoelectron spectra (XPS) were collected on a Kratos Axis Ultra DLD X-ray photoelectron spectrometer using a monochromatic Al K-alpha source for high resolution work. Energy correction using the lowest energy binding component of the $\mathrm{C} 1 \mathrm{~s}$ peak to $284.6 \mathrm{eV}$.

Photoelectrochemical experiments were carried out using a ThorLabs $375 \mathrm{~nm}$ LED with a maximum power of $1270 \mathrm{~mW}$. A collimating lens was attached to the mounted led to maintain a $1 \mathrm{~cm} 2$ spot size. Light intensity was quantified using a Thor Labs silicon photodiode. An Ocean Optics Flame UV-Vis Spectrometer was used to monitor the visible absorption spectra of Am solutions. This included an Ocean Optics DAL2000 light source and a custom built cell holder.

Atomic layer deposition (ALD) was performed using a Cambridge NanoTech Savannah S200 instrument with TDMAT (tetrakis(dimethylamino)titanium) as Ti precursor and Atomic layer deposition (ALD) was performed in a commercial reactor (Savannah S200, Cambridge Nanotech). Titanium dioxide $\left(\mathrm{TiO}_{2}\right)$ was deposited using tetrakis (dimethylamido) titanium, $\mathrm{Ti}\left(\mathrm{NMe}_{2}\right)_{4}(\mathrm{TDMAT}$, $99.999 \%$, Sigma-Aldrich), and water. The reactor temperature was $150{ }^{\circ} \mathrm{C}$. The TDMAT reservoir was kept at $75^{\circ} \mathrm{C}$. The TDMAT was pulsed into the reactor for $0.5 \mathrm{~s}$ and then held for $20 \mathrm{~s}$ before 
opening the pump valve and purging for $60 \mathrm{~s}$. ALD coating conditions were $150{ }^{\circ} \mathrm{C}$ and 20 torr of $\mathrm{N}_{2}$ carrier gas with a sequence of 0.5-s metal precursor dose, 20-s hold, 60-s $\mathrm{N}_{2}$ purge, 0.02-s $\mathrm{H}_{2} \mathrm{O}$ dose, 20-s hold, 60-s $\mathrm{N}_{2}$ purge.

The generator/collector experiments for $\mathrm{O}_{2}$ detection used a four electrode setup along with a bipotentiostat. A nanolTO and FTO working electrodes in conjunction with a Pt counter and SCE reference electrode were used. One FTO (generator) electrode was prepared as described for the nanolTO photoanodes used in this study; the other FTO (collector) electrode was unmodified. Assembly of the generator/collector setup involved placing the two FTO electrodes with the conductive sides facing with narrow $1 \mathrm{~mm}$ thick glass spacers between the lateral edges and sealing the sides with epoxy (Hysol). Prepared in this way, space between the two FTO electrodes will fill with electrolyte by capillary action when the cell is placed in solution.

To measure the faradaic efficiency for $\mathrm{O}_{2}$ production, the charge passed at the generator electrode during the illumination phase of the experiment was compared to the total charge passed at the collector electrode (poised at $-0.85 \mathrm{~V}$ vs. $\mathrm{Ag} / \mathrm{AgCl}$ ) during the entire experiment. The faradaic efficiency was corrected for the collection efficiency of the generator/collector setup $(70 \%)$ that was determined experimentally.

Caution: ${ }^{243} \mathrm{Am}$ is a radioactive isotope, and should only be used in appropriate authorized facilities. All experiments involving Am were carried out in a radiologically designated fumehood with a HEPA (high-efficiency particulate-absorbing) filtered exhaust. The air outside the fumehood was continuously monitored to ensure no airborne contamination. Americium stock solutions of ${ }^{243} \mathrm{Am}$ in $0.1 \mathrm{M}$ optima grade nitric acid were on hand at Idaho National Laboratory (2 $\mathrm{mM}$ ). These were further diluted with nitric acid to yield solutions with a total americium concentration of $1.0 \mathrm{mM}$ for all working solutions. 

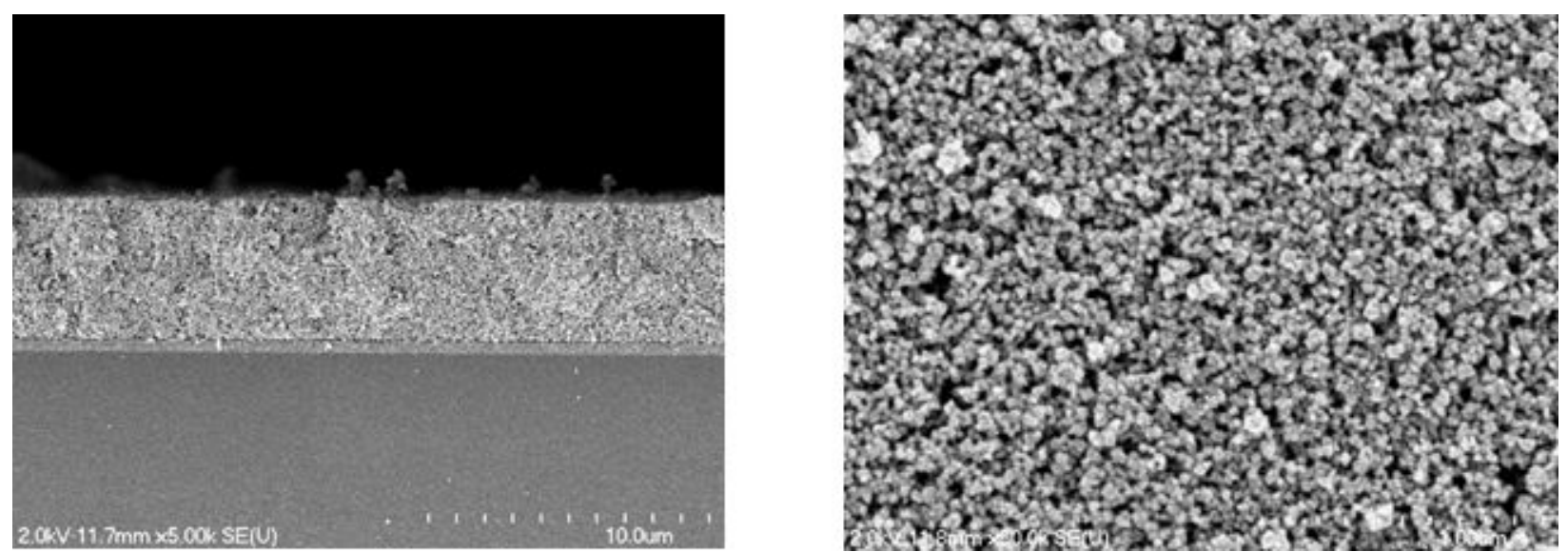

Figure S1. Cross-sectional SEM image of a nanolTO electrode after annealing at $500{ }^{\circ} \mathrm{C}$.
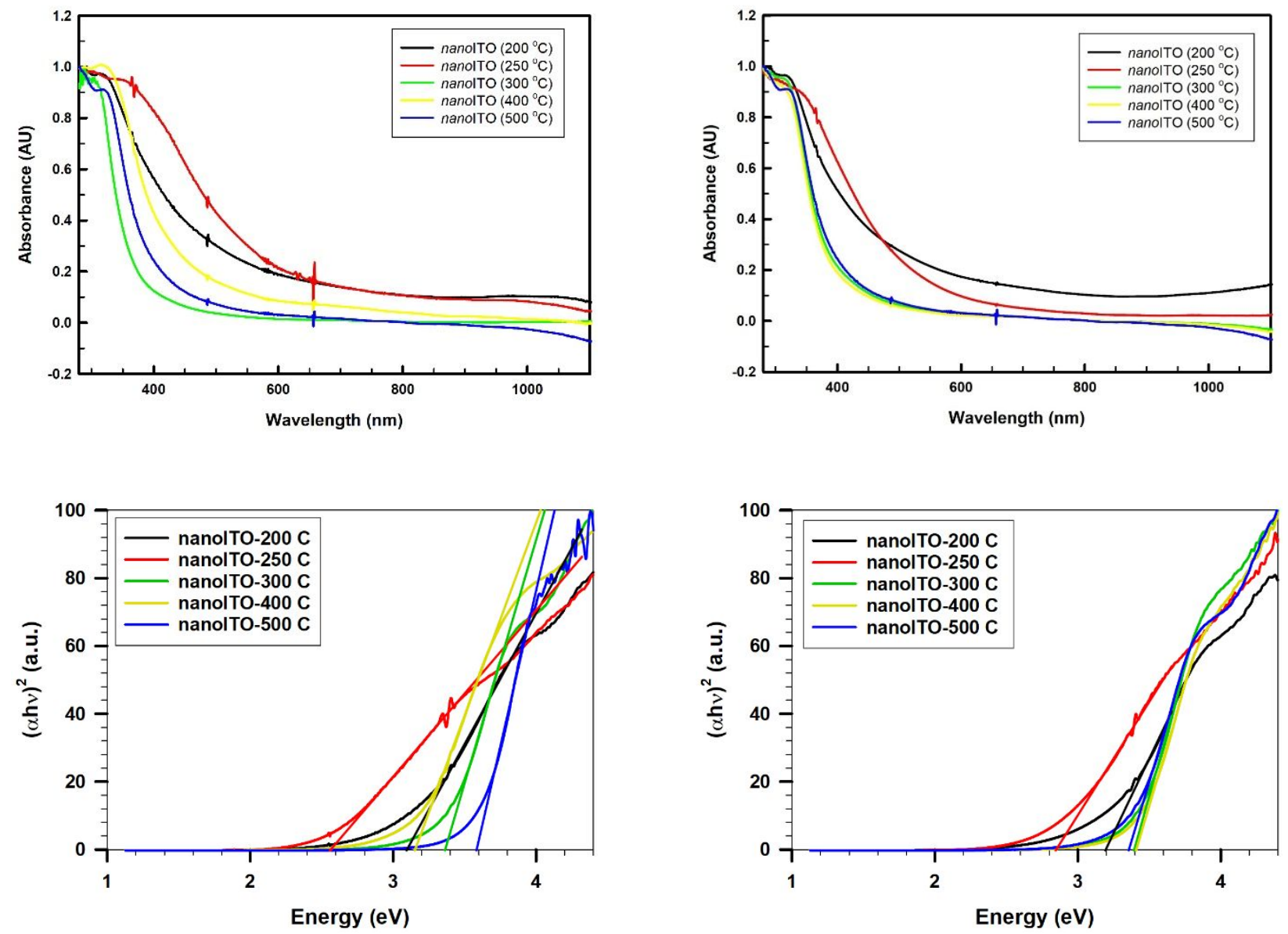

Figure S2. Top: UV-vis spectroscopy of nanolTO slides, and Bottom: Tauc plots for nanolTO slides, annealed at: $200{ }^{\circ} \mathrm{C}$ (Black), $250{ }^{\circ} \mathrm{C}$ (Red), $300{ }^{\circ} \mathrm{C}$ (Green), $400{ }^{\circ} \mathrm{C}$ (Yellow), and $500{ }^{\circ} \mathrm{C}$ (Blue) prior to electrochemical experiments at pH 1 (Left) and $\mathrm{pH} 7$ (Right). 


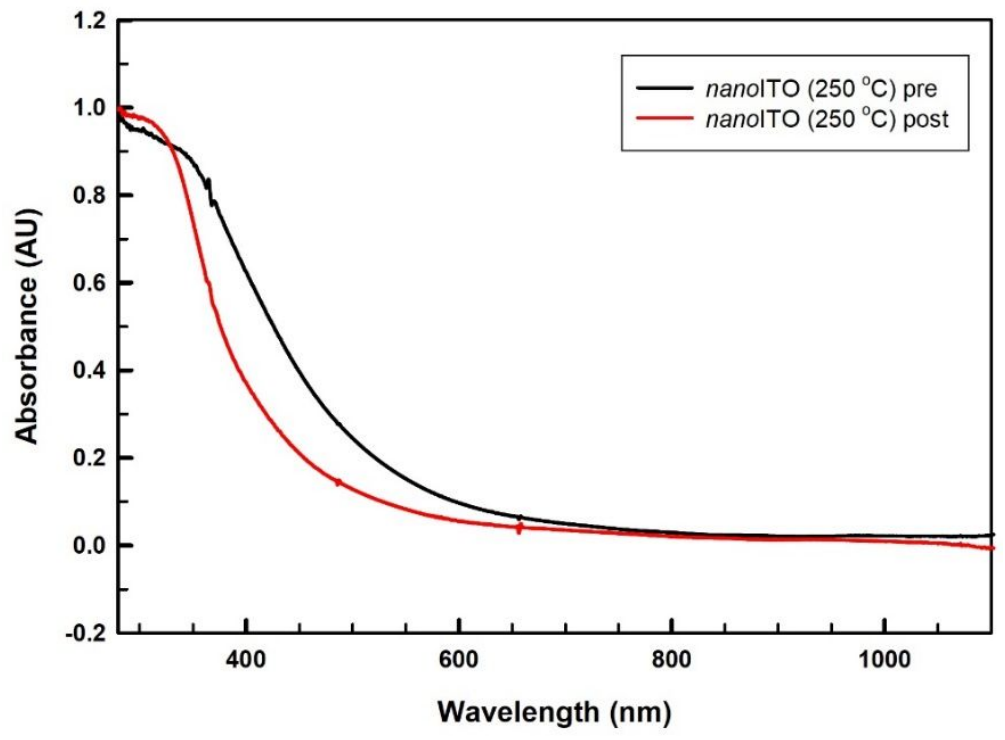

Figure S3. UV-vis spectroscopy of nanolTO $\left(250{ }^{\circ} \mathrm{C}\right)$ before (pre, black) and after oxidative electrochemical cyclic voltammograms (post, red).

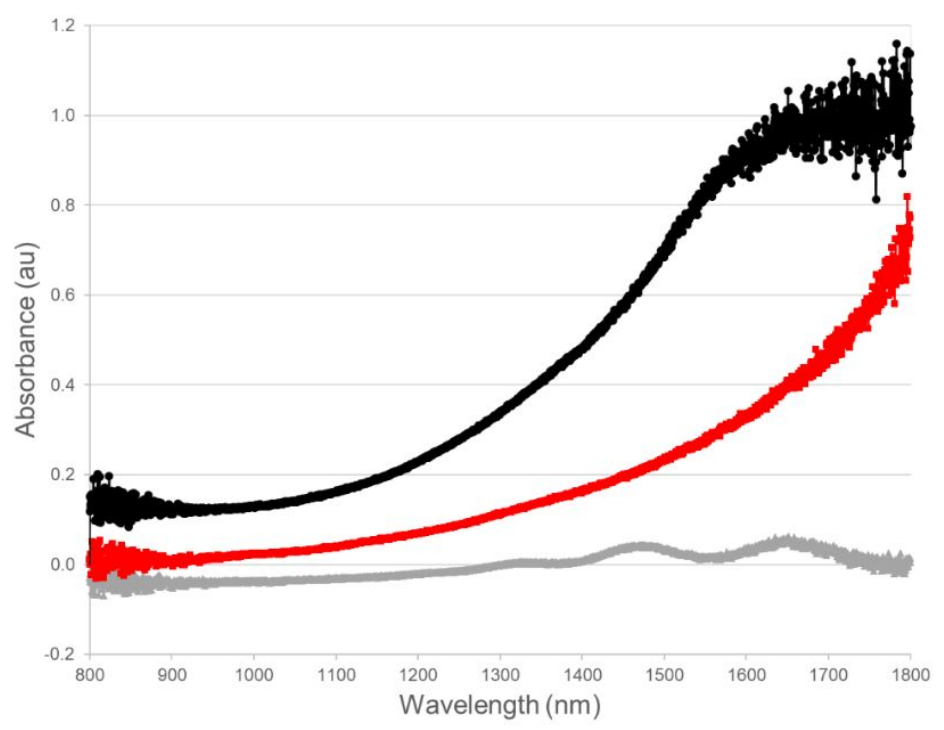

Figure S4. vis-NIR spectroscopy of nanolTO $\left(20{ }^{\circ} \mathrm{C}\right)$ (black), nanolTO $\left(250{ }^{\circ} \mathrm{C}\right)(\mathrm{red})$, and $\mathrm{TiO}_{2}$ (gray). 


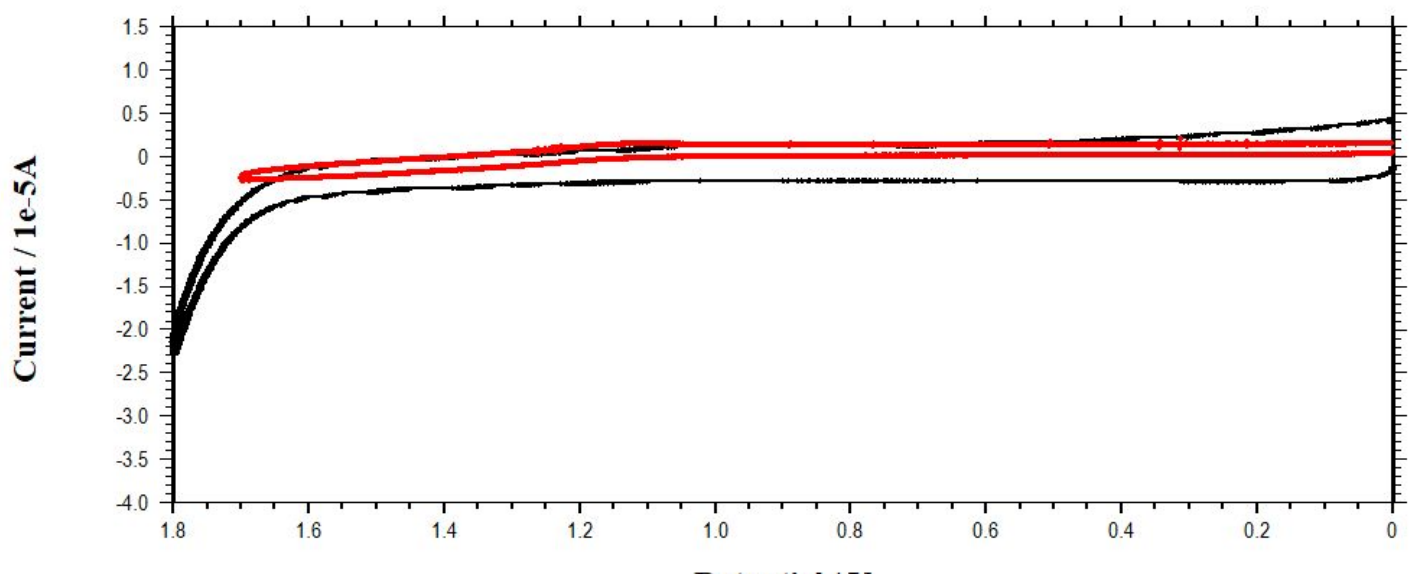

Potential / V

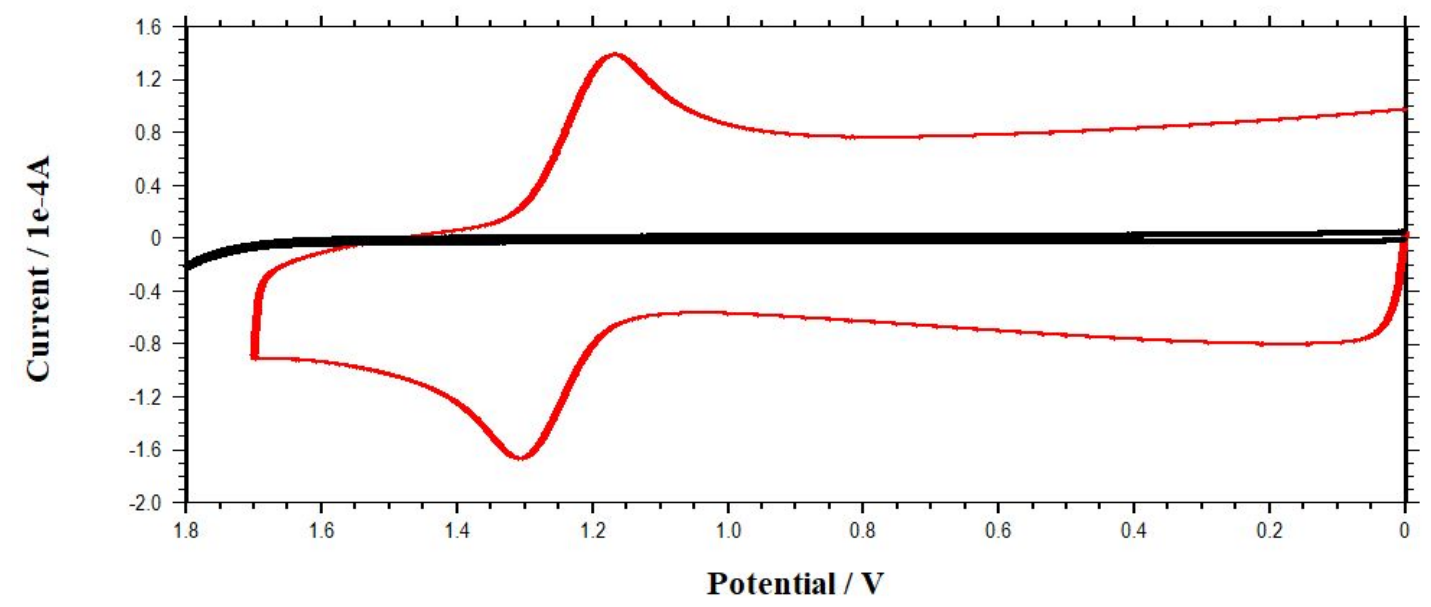

Figure S5. (top) CVs of $1.0 \mathrm{mM} \mathrm{Ru(bpy)}{ }_{3}{ }^{2+}$ in acetonitrile, $0.1 \mathrm{M}\left[n \mathrm{nu}_{4}\right] \mathrm{PF}_{6}$ at a $1 \mathrm{~cm}^{2}$ nanolTO $(200$ ${ }^{\circ}$ C) electrode (black) and a $1 \mathrm{~cm}^{2} \mathrm{TiO}_{2}-\left(\mathrm{TiO}_{2}\right)_{40}$ electrode (red), $\mathrm{v}=0.1 \mathrm{~V} / \mathrm{s}$; (bottom) CVs of 1.0 $\mathrm{mM} \mathrm{Ru}(\mathrm{bpy})_{3}{ }^{2+}$ in acetonitrile, $0.1 \mathrm{M}\left[\mathrm{nBu}_{4}\right] \mathrm{PF}_{6}$ at a $1 \mathrm{~cm}^{2}$ nanolTO $\left(200{ }^{\circ} \mathrm{C}\right.$ ) electrode (black) and a $1 \mathrm{~cm}^{2}$ nanolTO $\left(500^{\circ} \mathrm{C}\right.$ ) electrode $(\mathrm{red}), \mathrm{v}=0.1 \mathrm{~V} / \mathrm{s}$. 


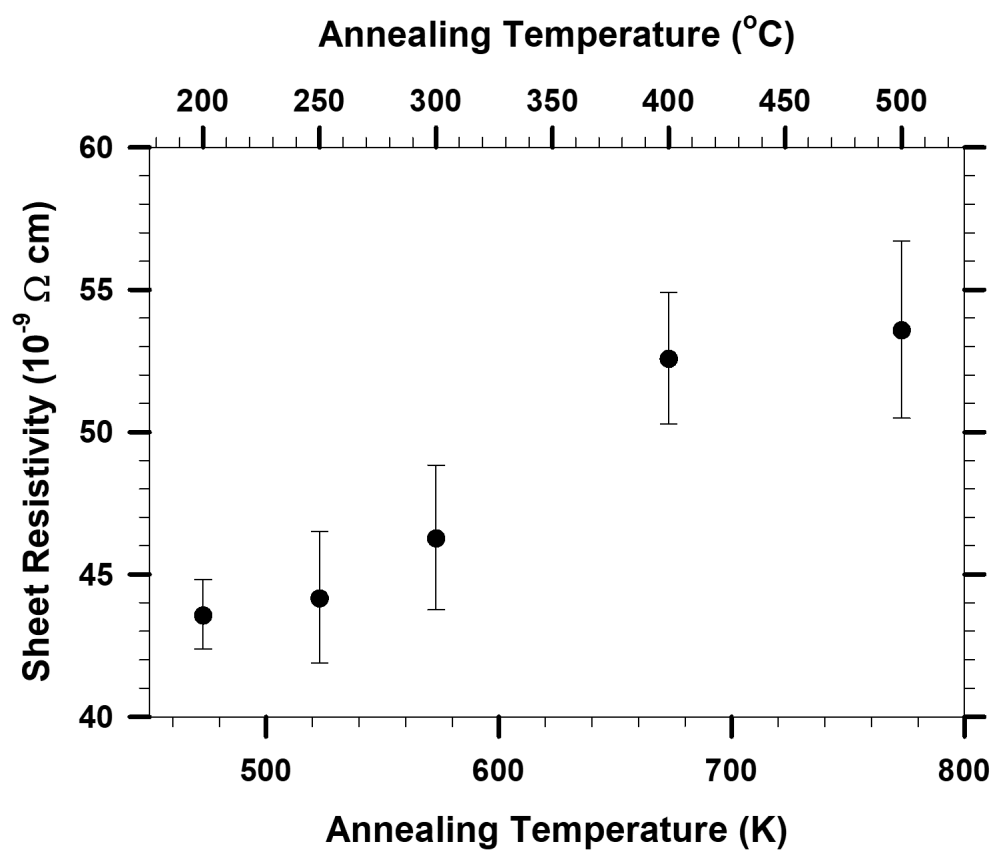

Figure S6. Resistivity measurements for nanolTO annealed at different temperatures using a 4point conductivity probe.
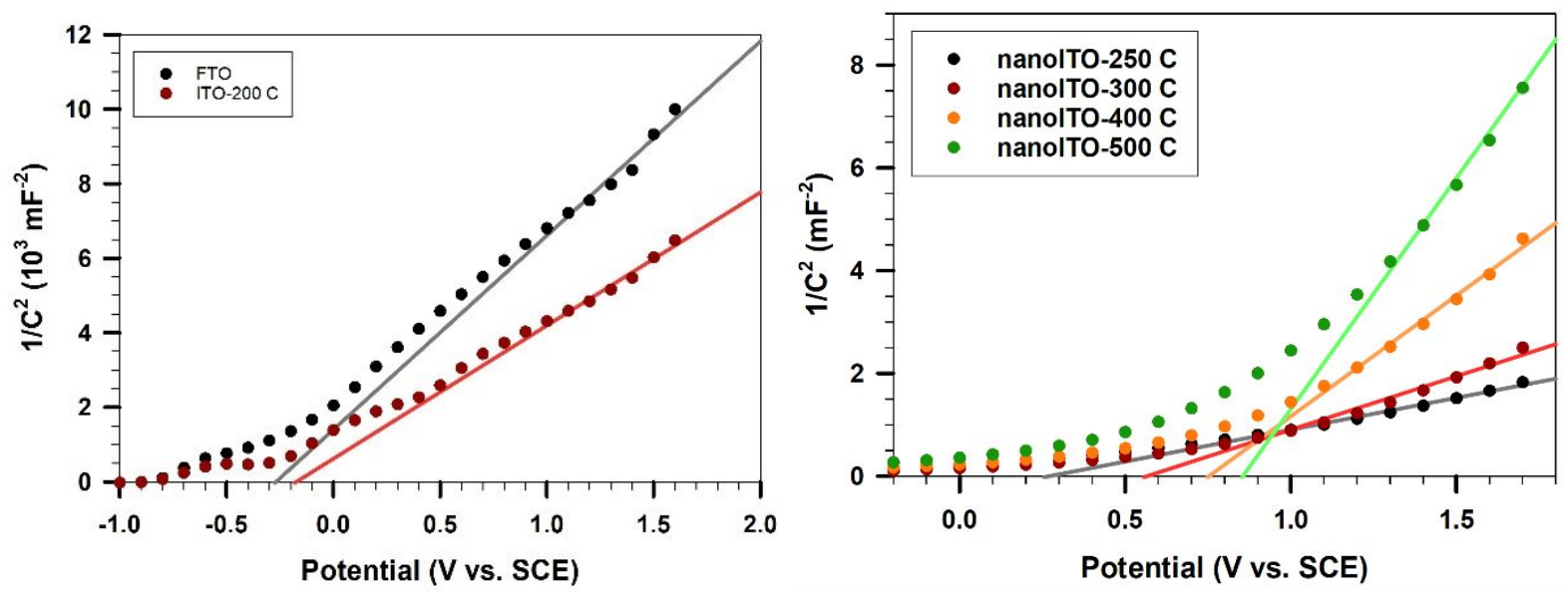

Figure S7. Mott-Schottky plots for Left: planarFTO (Black) and nanolTO slides annealed at $200^{\circ} \mathrm{C}$ (Red). Linear regression between $1.1 \mathrm{~V}$ and $1.6 \mathrm{~V}$ yielded $\mathrm{C}^{-2}=0$ of $-0.26 \mathrm{~V}$, and $-0.17 \mathrm{~V}$; and Right: for nanolTO slides annealed at: $250{ }^{\circ} \mathrm{C}$ (Black), $300{ }^{\circ} \mathrm{C}$ (Red), $400{ }^{\circ} \mathrm{C}$ (Orange), and $500{ }^{\circ} \mathrm{C}$ (Green). Linear regression between $1.2 \mathrm{~V}$ and $1.7 \mathrm{~V}$ yielded $\mathrm{C}^{-2}=0.26 \mathrm{~V}, 0.56 \mathrm{~V}, 0.75$ $\mathrm{V}$, and $0.86 \mathrm{~V}$ for each respective nanolTO sample. Relative to nanolTO annealed at $250 \mathrm{C}$, the relative dopant density for nanolTO is 0.60 (300 C), 0.26 (400 C), and $0.14(500 \mathrm{C})$. 


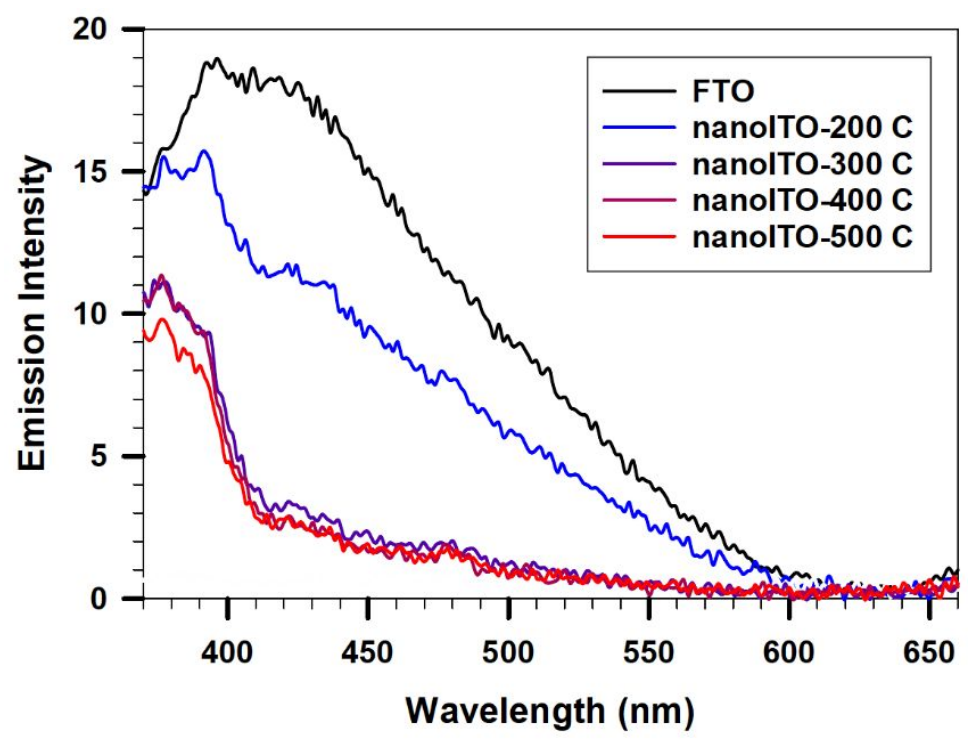

Figure S8. Emission spectra for FTO (Black), and nanolTO electrodes annealed at $200^{\circ} \mathrm{C}$ (Blue), $300{ }^{\circ} \mathrm{C}$ (Purple), $400{ }^{\circ} \mathrm{C}$ (Fuchsia), and $500{ }^{\circ} \mathrm{C}$ (Red) in $0.1 \mathrm{M} \mathrm{HNO}_{3}$ using a $350 \mathrm{~nm}$ excitation wavelength. Samples were placed at a $45^{\circ}$ angle to the detector to direct reflected light away.
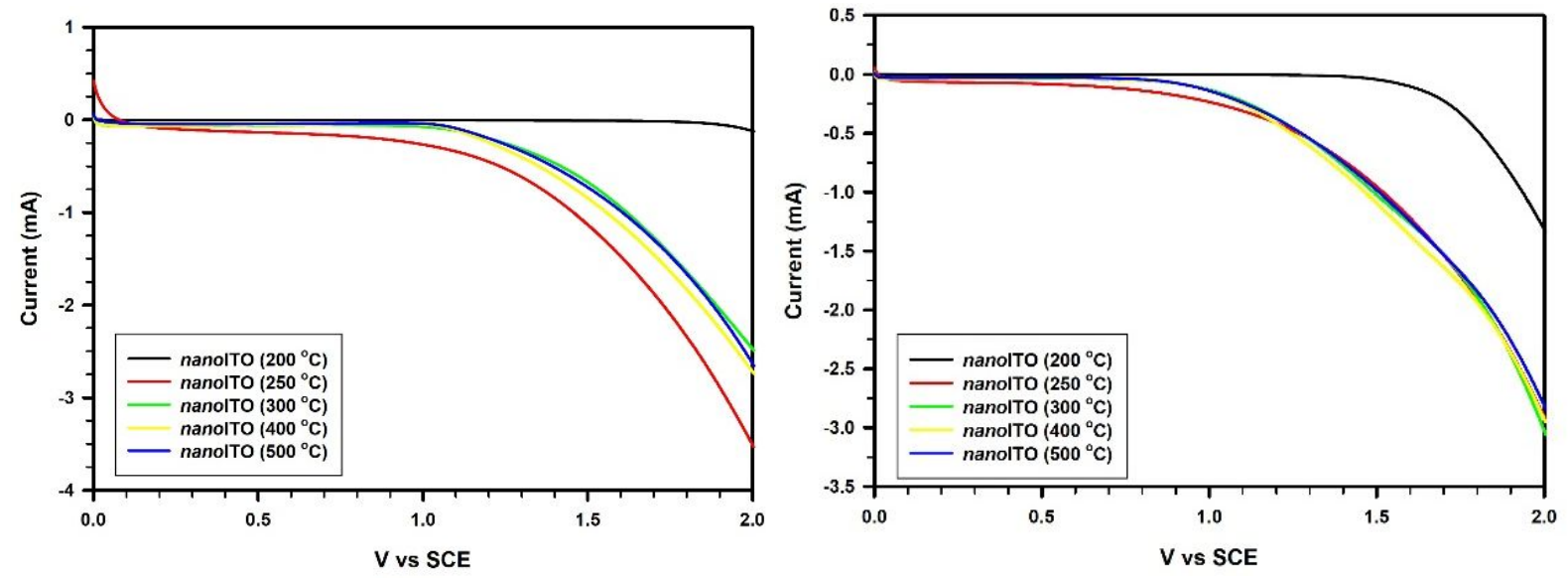

Figure S9. LSVs under $100 \mathrm{~mW} / \mathrm{cm}^{2} 375 \mathrm{~nm}$ illumination for each nanolTO electrode annealed at varying temperatures in $\mathrm{pH} 1,0.1 \mathrm{M} \mathrm{HNO}_{3}$ (left) and $\mathrm{pH}$ 7, $0.2 \mathrm{M}$ Phosphate (Right) 

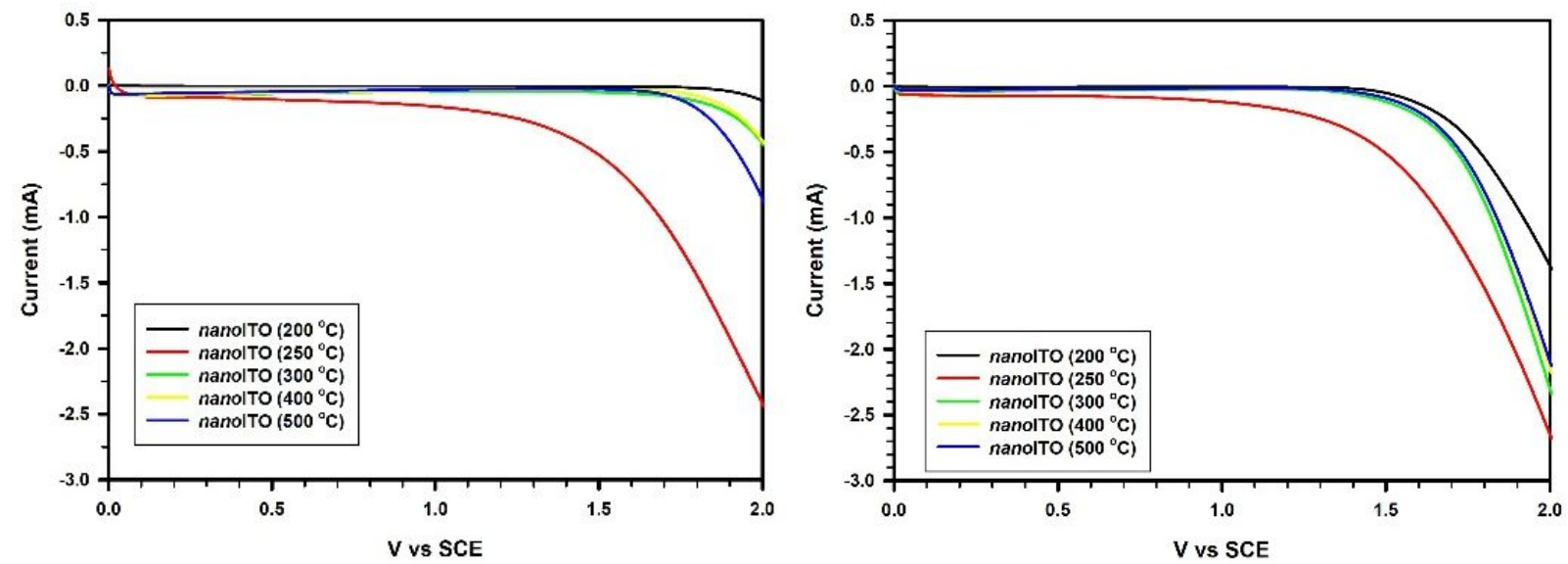

Figure S10. LSVs in the dark of each nanolTO electrode annealed at varying temperatures in $\mathrm{pH}$ 1, 0.1 $\mathrm{M} \mathrm{HNO}_{3}$ (left) and $\mathrm{pH}$ 7, 0.2 M Phosphate (Right)
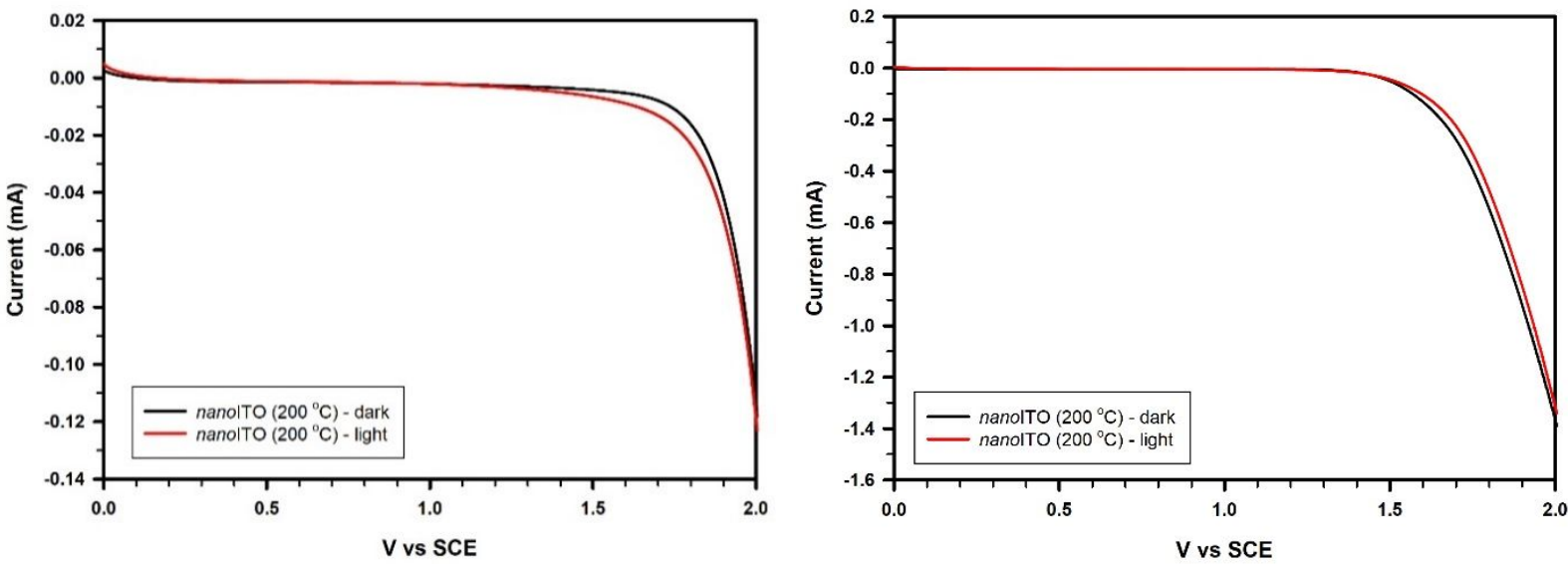

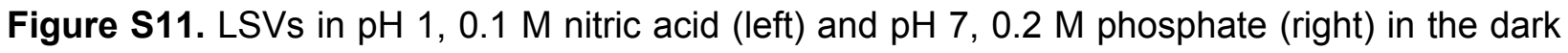
and under $100 \mathrm{~mW} / \mathrm{cm}^{2} 375 \mathrm{~nm}$ illumination of $1 \mathrm{~cm}^{2}$ nanolTO slides prepared at $200{ }^{\circ} \mathrm{C}$.
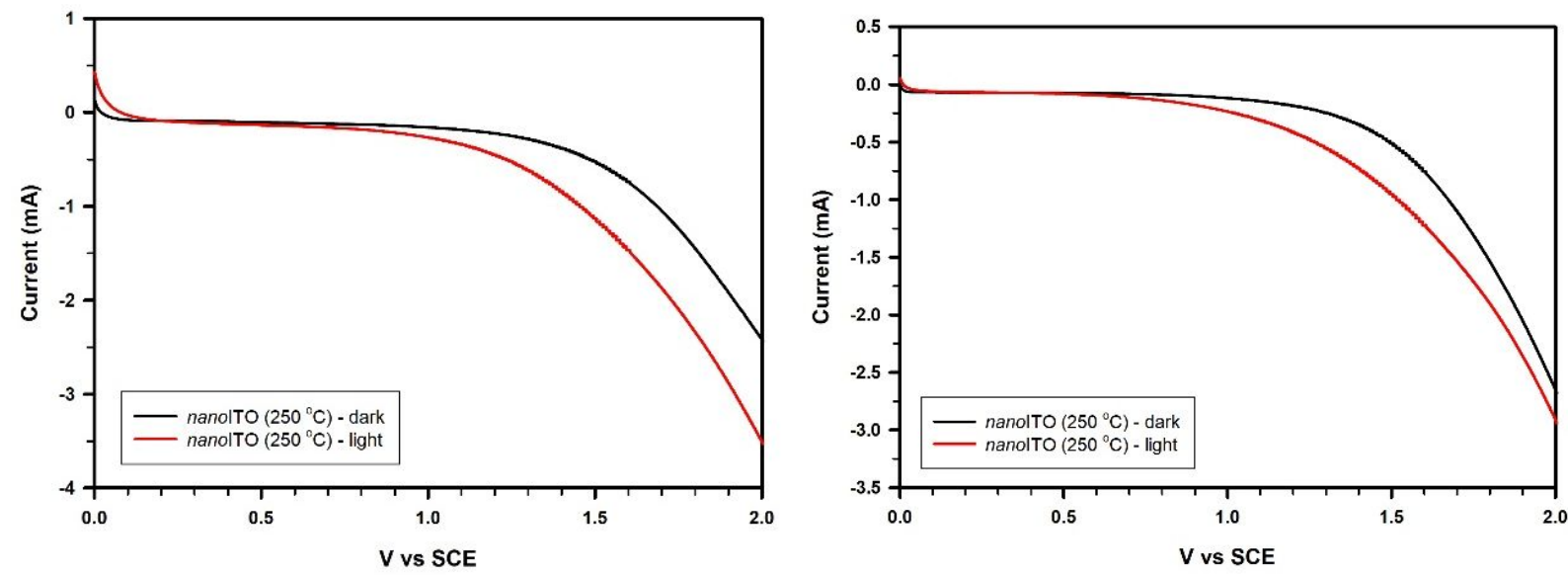

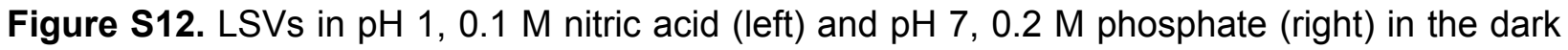
and under $100 \mathrm{~mW} / \mathrm{cm}^{2} 375 \mathrm{~nm}$ illumination of $1 \mathrm{~cm}^{2}$ nanolTO slides prepared at $250{ }^{\circ} \mathrm{C}$. 

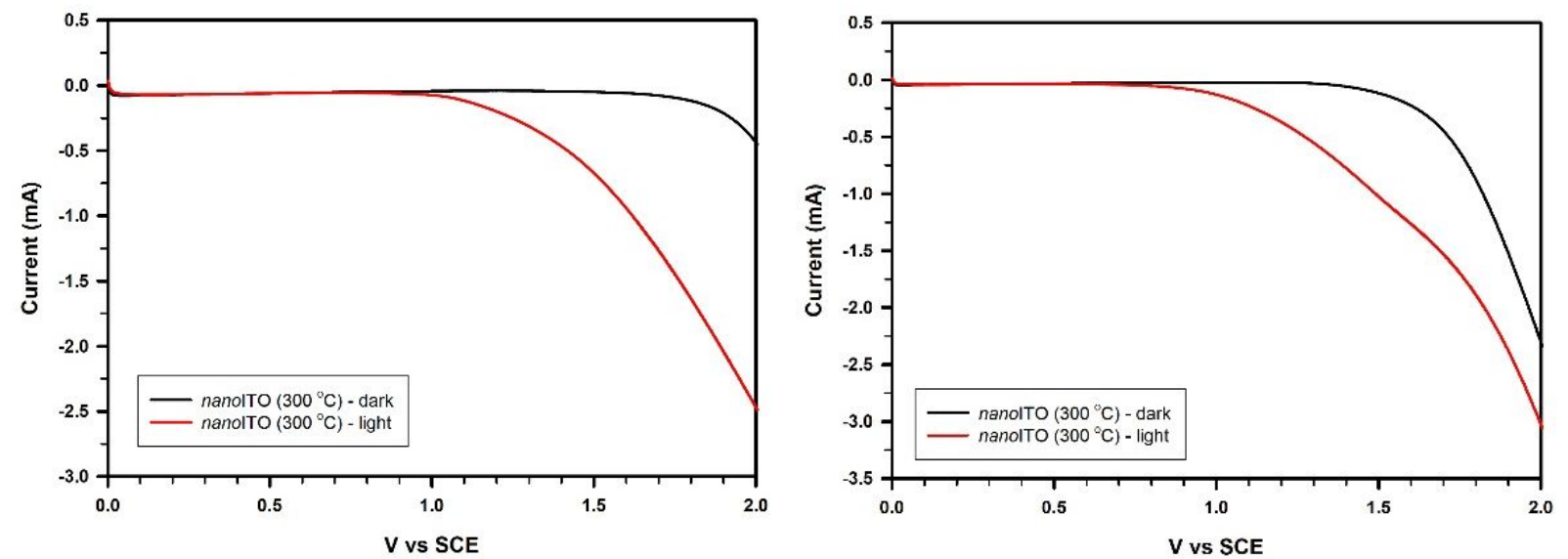

Figure S13. LSVs in $\mathrm{pH} 1,0.1 \mathrm{M}$ nitric acid (left) and $\mathrm{pH} 7,0.2 \mathrm{M}$ phosphate (right) in the dark and under $100 \mathrm{~mW} / \mathrm{cm}^{2} 375 \mathrm{~nm}$ illumination of $1 \mathrm{~cm}^{2}$ nanolTO slides prepared at $300{ }^{\circ} \mathrm{C}$.
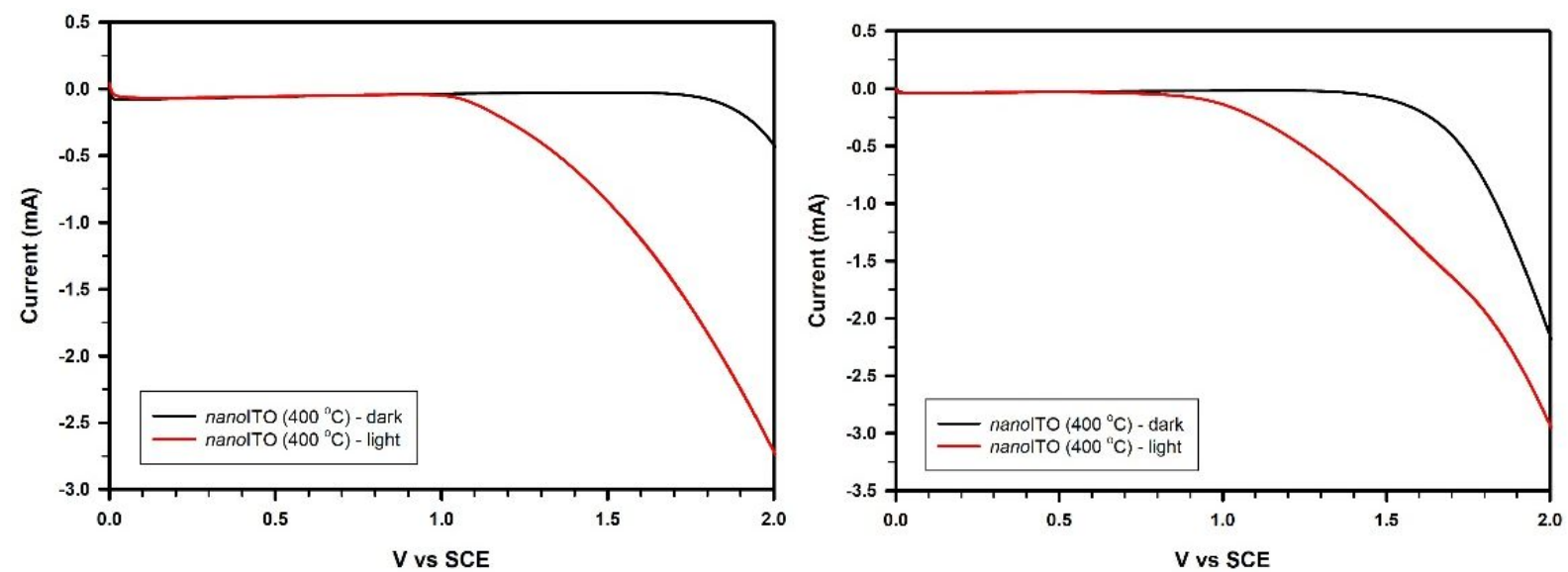

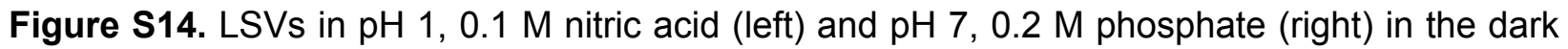
and under $100 \mathrm{~mW} / \mathrm{cm}^{2} 375 \mathrm{~nm}$ illumination of $1 \mathrm{~cm}^{2}$ nanolTO slides prepared at $400{ }^{\circ} \mathrm{C}$.
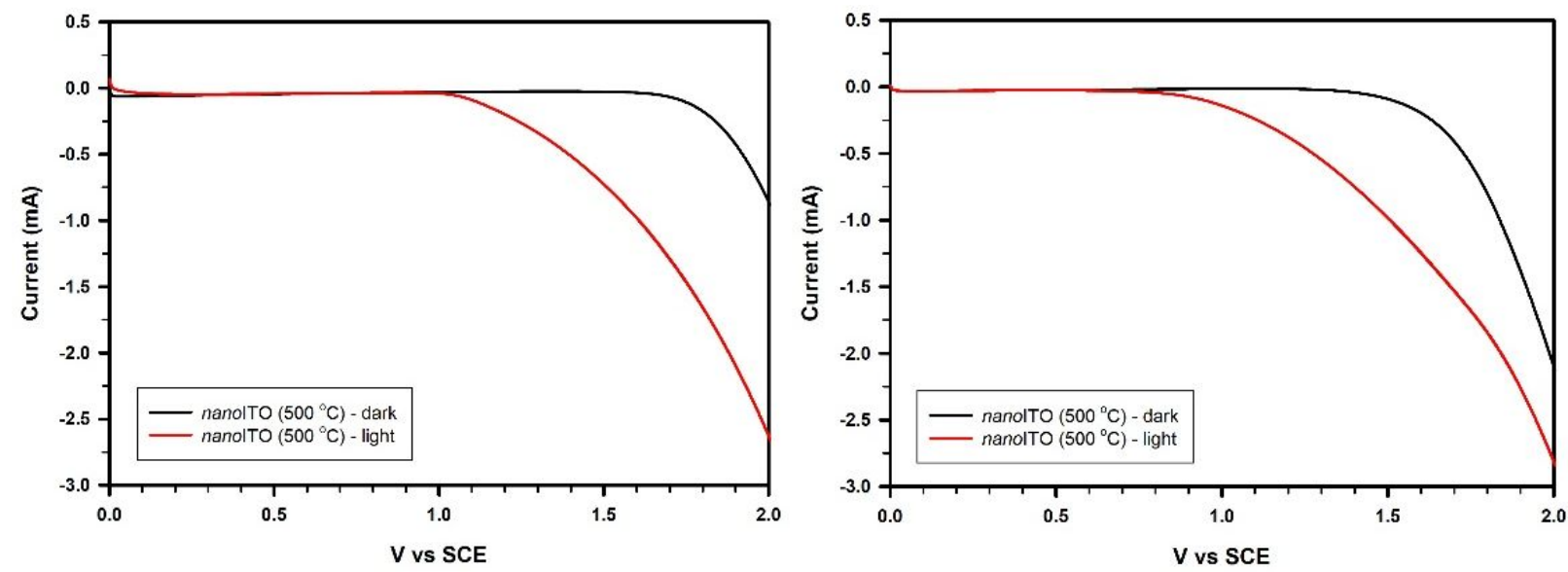

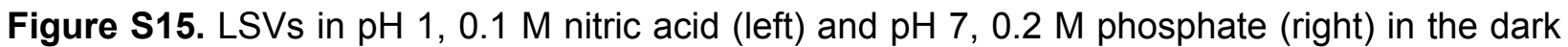
and under $100 \mathrm{~mW} / \mathrm{cm}^{2} 375 \mathrm{~nm}$ illumination of $1 \mathrm{~cm}^{2}$ nanolTO slides prepared at $500{ }^{\circ} \mathrm{C}$. 

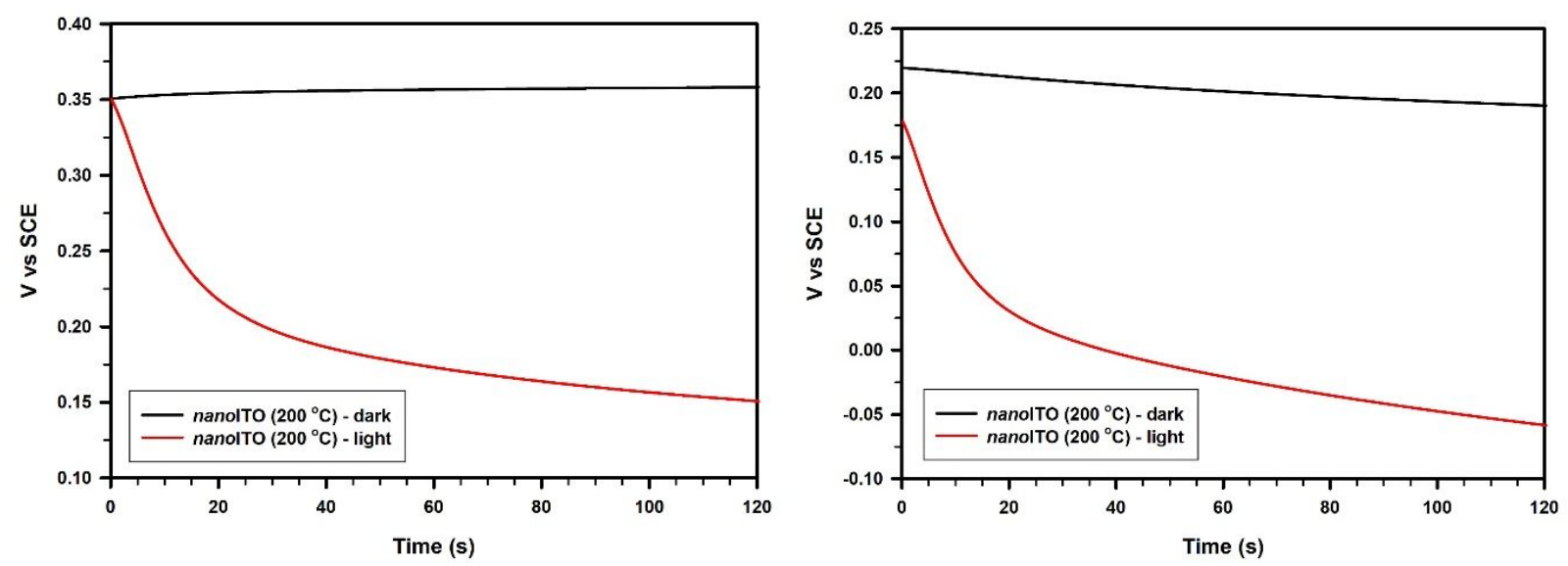

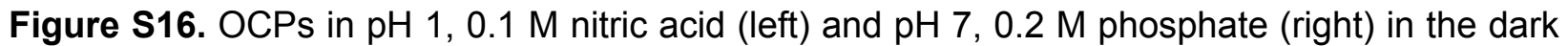
and under $100 \mathrm{~mW} / \mathrm{cm}^{2} 375 \mathrm{~nm}$ illumination of $1 \mathrm{~cm}^{2}$ nanolTO slides prepared at $200{ }^{\circ} \mathrm{C}$.
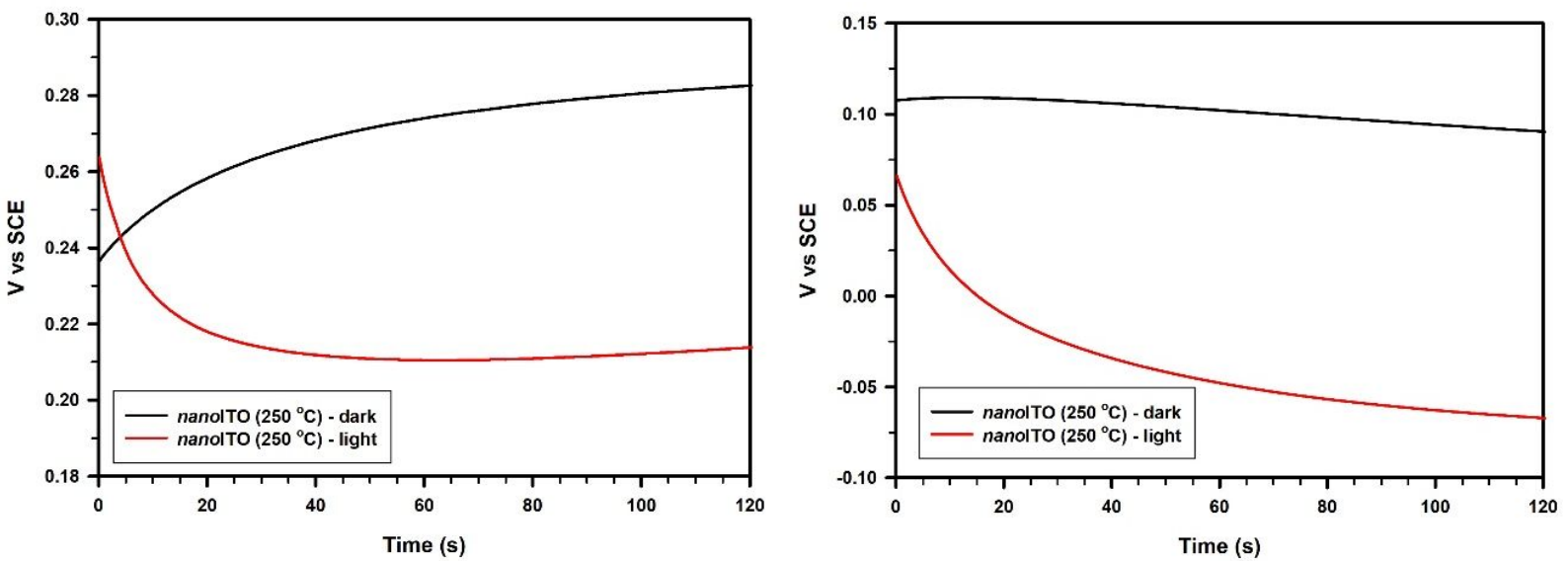

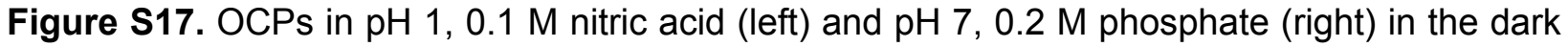
and under $100 \mathrm{~mW} / \mathrm{cm}^{2} 375 \mathrm{~nm}$ illumination of $1 \mathrm{~cm}^{2}$ nanolTO slides prepared at $250{ }^{\circ} \mathrm{C}$.
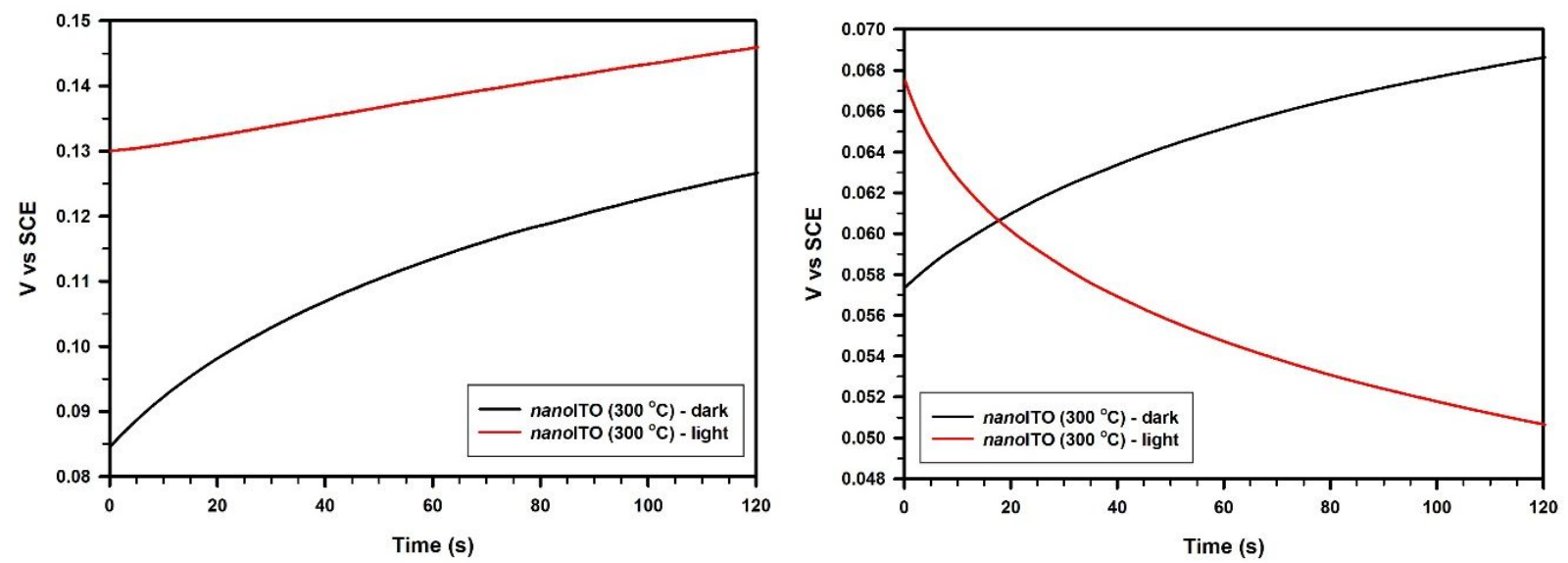

Figure S18. OCPs in $\mathrm{pH} \mathrm{1,0.1} \mathrm{M} \mathrm{nitric} \mathrm{acid} \mathrm{(left)} \mathrm{and} \mathrm{pH} 7,0.2 \mathrm{M}$ phosphate (right) in the dark and under $100 \mathrm{~mW} / \mathrm{cm}^{2} 375 \mathrm{~nm}$ illumination of $1 \mathrm{~cm}^{2}$ nanolTO slides prepared at $300{ }^{\circ} \mathrm{C}$. 

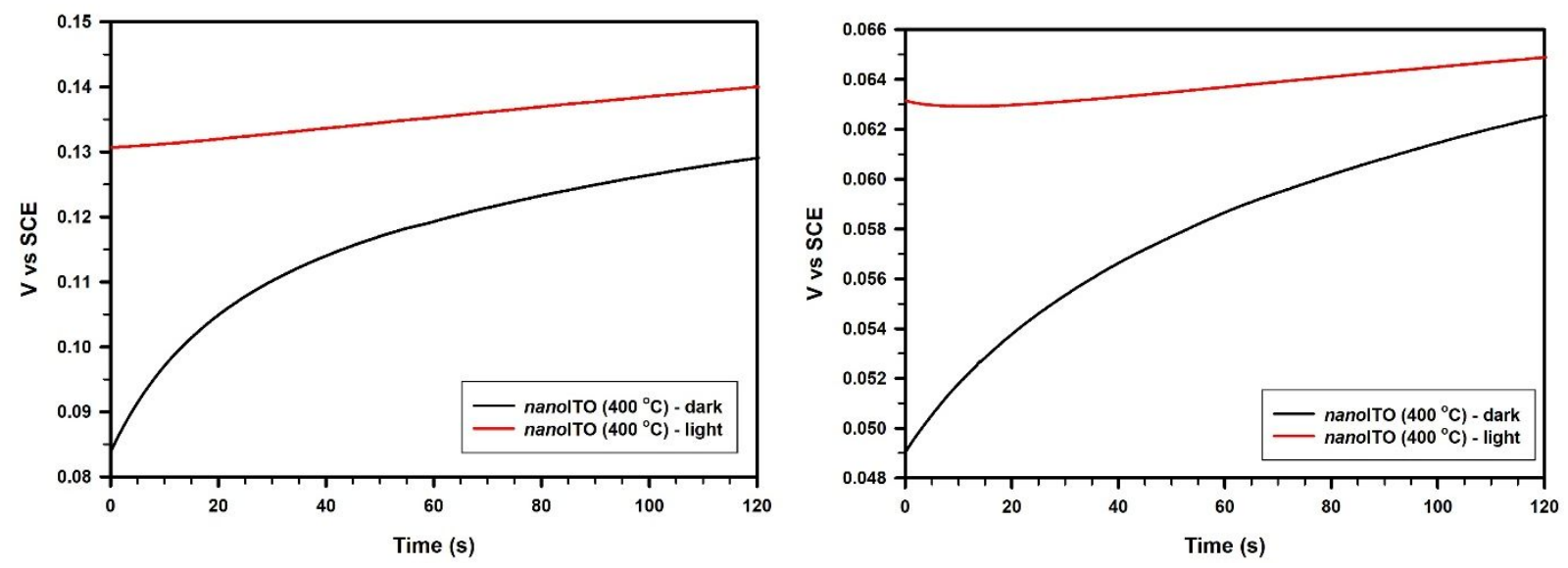

Figure S19. OCPs in $\mathrm{pH} 1,0.1 \mathrm{M}$ nitric acid (left) and $\mathrm{pH} 7,0.2 \mathrm{M}$ phosphate (right) in the dark and under $100 \mathrm{~mW} / \mathrm{cm}^{2} 375 \mathrm{~nm}$ illumination of $1 \mathrm{~cm}^{2}$ nanolTO slides prepared at $400{ }^{\circ} \mathrm{C}$.
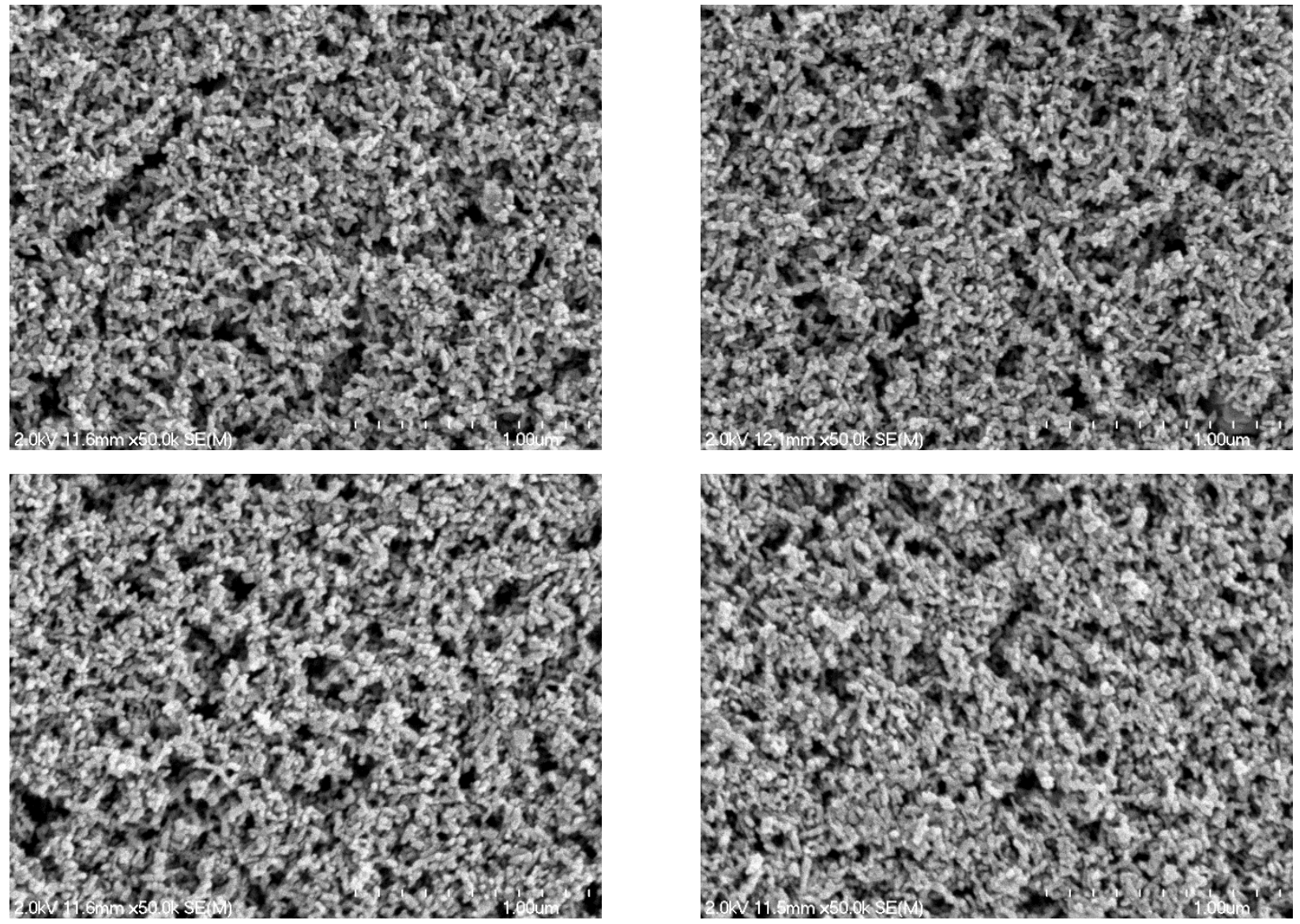

Figure S20. SEM Images of nanolTO films Top Left: after soaking in $0.1 \mathrm{M} \mathrm{HNO}_{3}$ for $6 \mathrm{~h}$; Top Right: after UV (375 nm) illumination for $6 \mathrm{~h}$; Bottom Left: after bulk electrolysis at $1.4 \mathrm{~V}$ vs. SCE for $6 \mathrm{~h}$; and Bottom Right: after $6 \mathrm{~h}$ of combined photoelectrolysis using UV illumination ( $375 \mathrm{~nm}$ ) and a $1.4 \mathrm{~V}$ bias. 


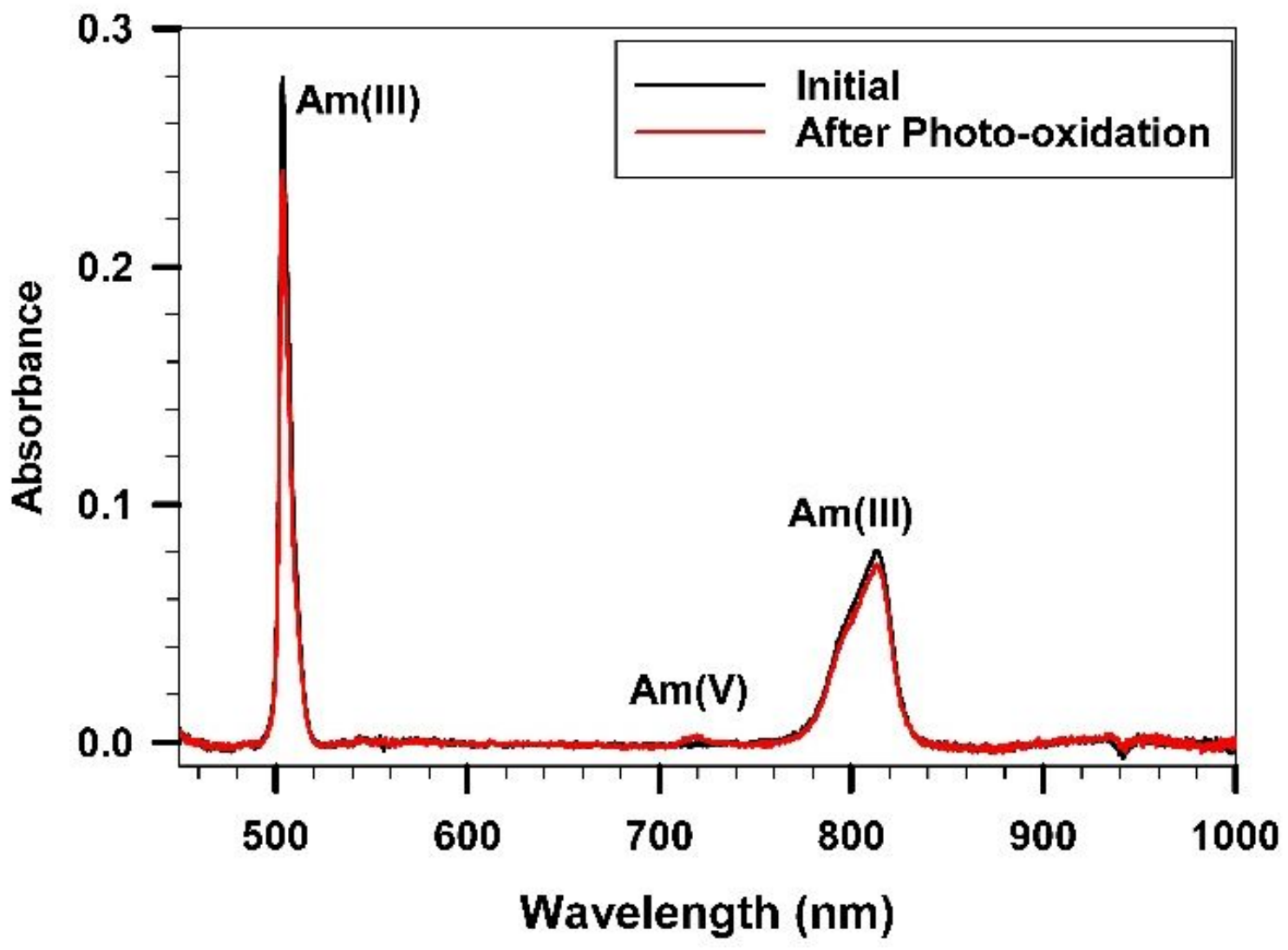

Figure S21. UV-vis spectra from spectroelectrochemistry of ${ }^{243} \mathrm{Am}$ solution during photolysis with nanolTO $\left(500^{\circ} \mathrm{C}\right)$ under UV illumination.

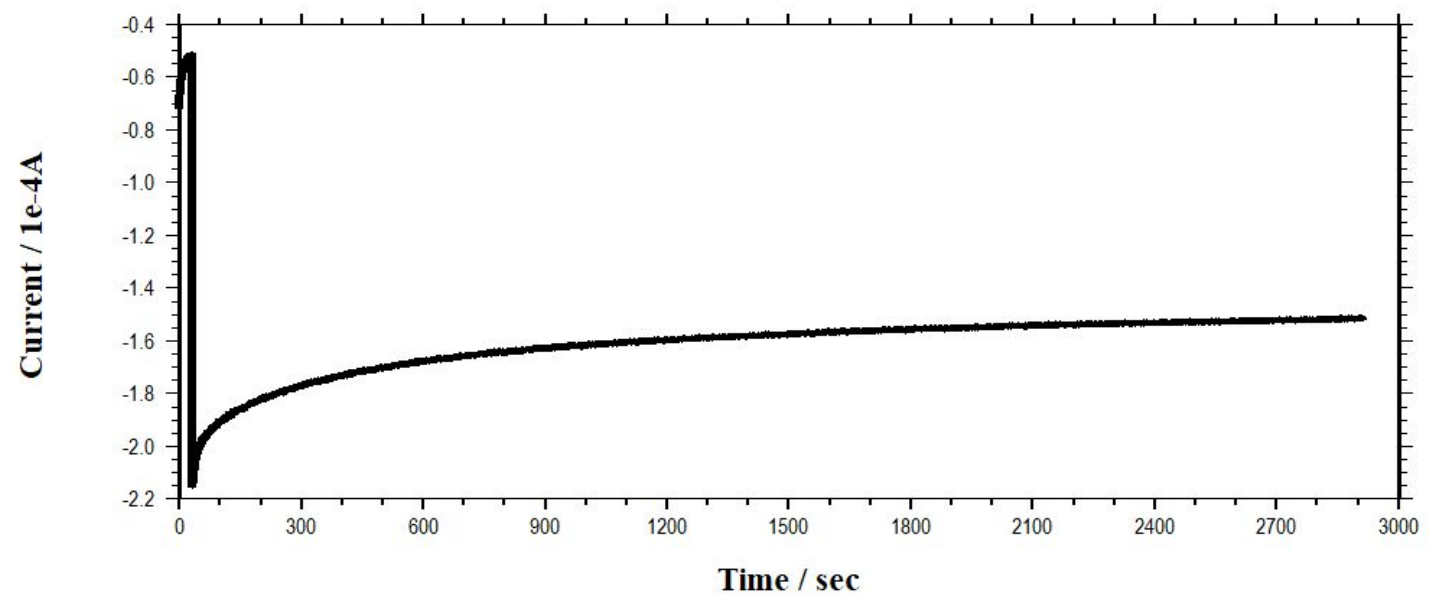

Figure S22. Current-time trace of a $1 \mathrm{~cm}^{2}$ nanolTO(500 oC) electrode in $1.0 \mathrm{mM}^{243} \mathrm{Am}^{3+}$ in $\mathrm{pH} 1$, $0.1 \mathrm{M}$ nitric acid, applied $1.75 \mathrm{~V}$ vs SCE with $100 \mathrm{~mW} / \mathrm{cm}^{2}$ UV illumination $(375 \mathrm{~nm})$. 

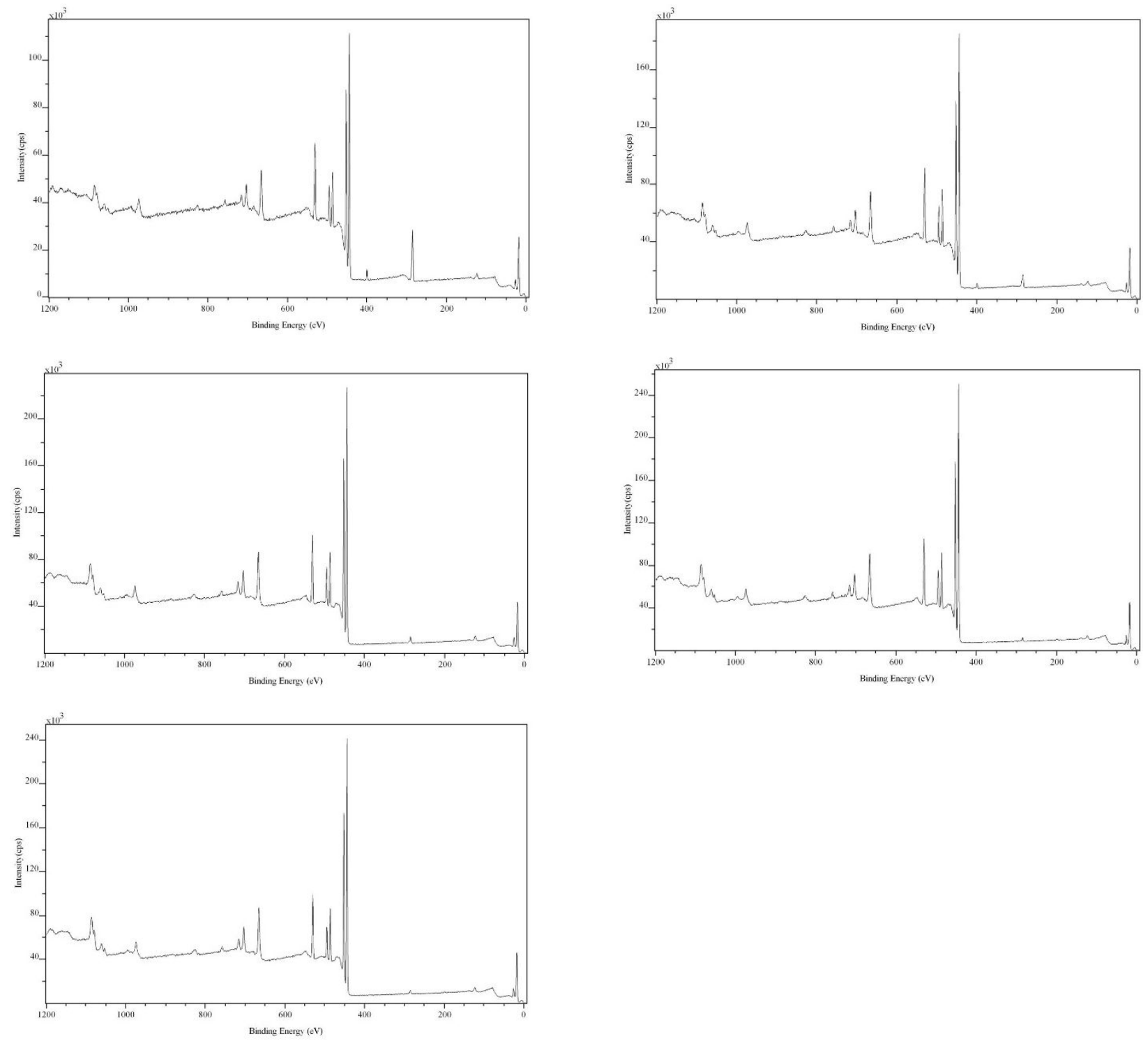

Figure S23. Survey XPS spectra of nanolTO electrodes annealed at: Top Left: 200 C; Top Right: 250 C; Middle Left: 300 C; Middle Right: 400 C; Bottom: 500 C. 

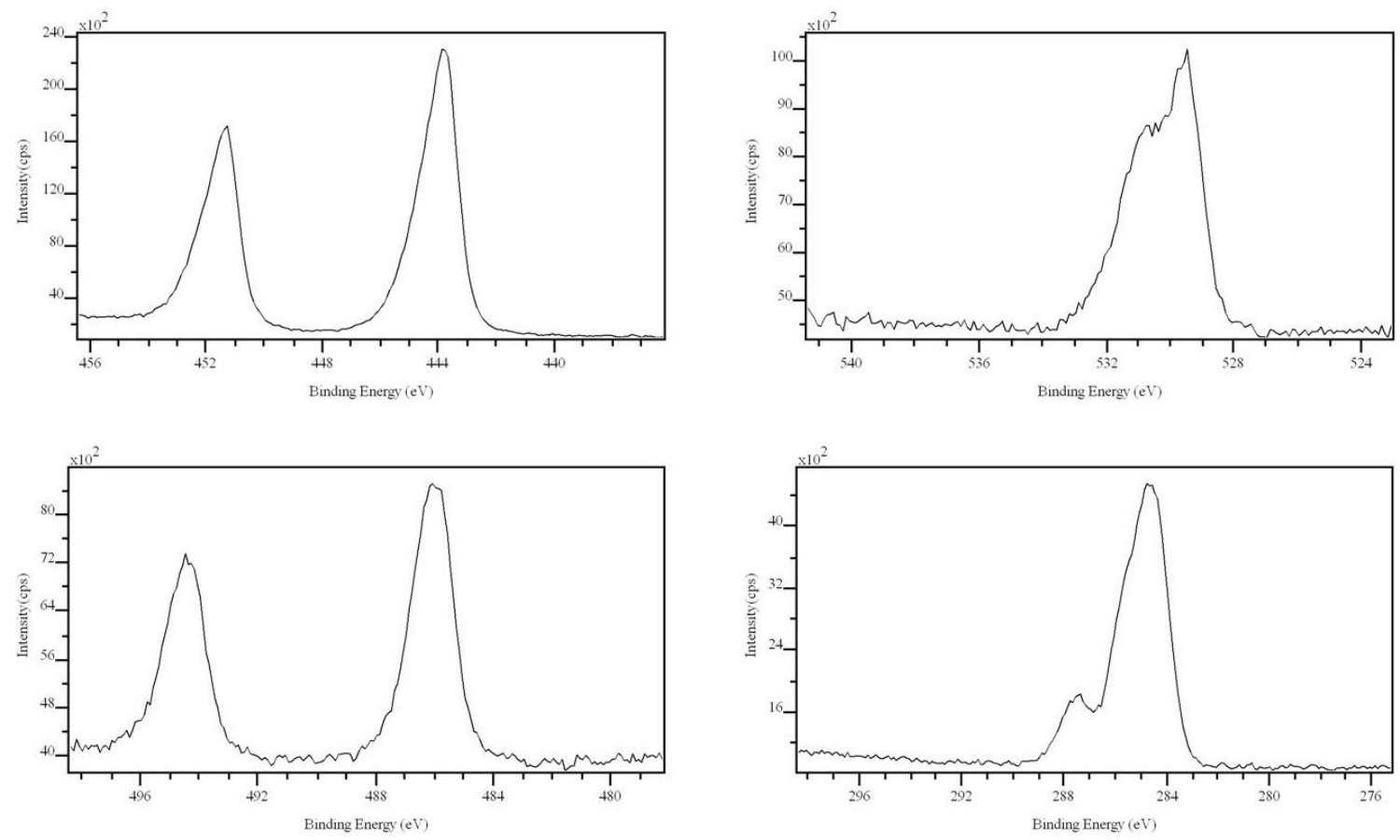

Figure S24. High resolution XPS spectra for nanolTO annealed at 200 C. Top Left: In-3d signals; Top Right: O-1s signals; Bottom Left: Sn-3d signals; and Bottom Right: C-1s signals.
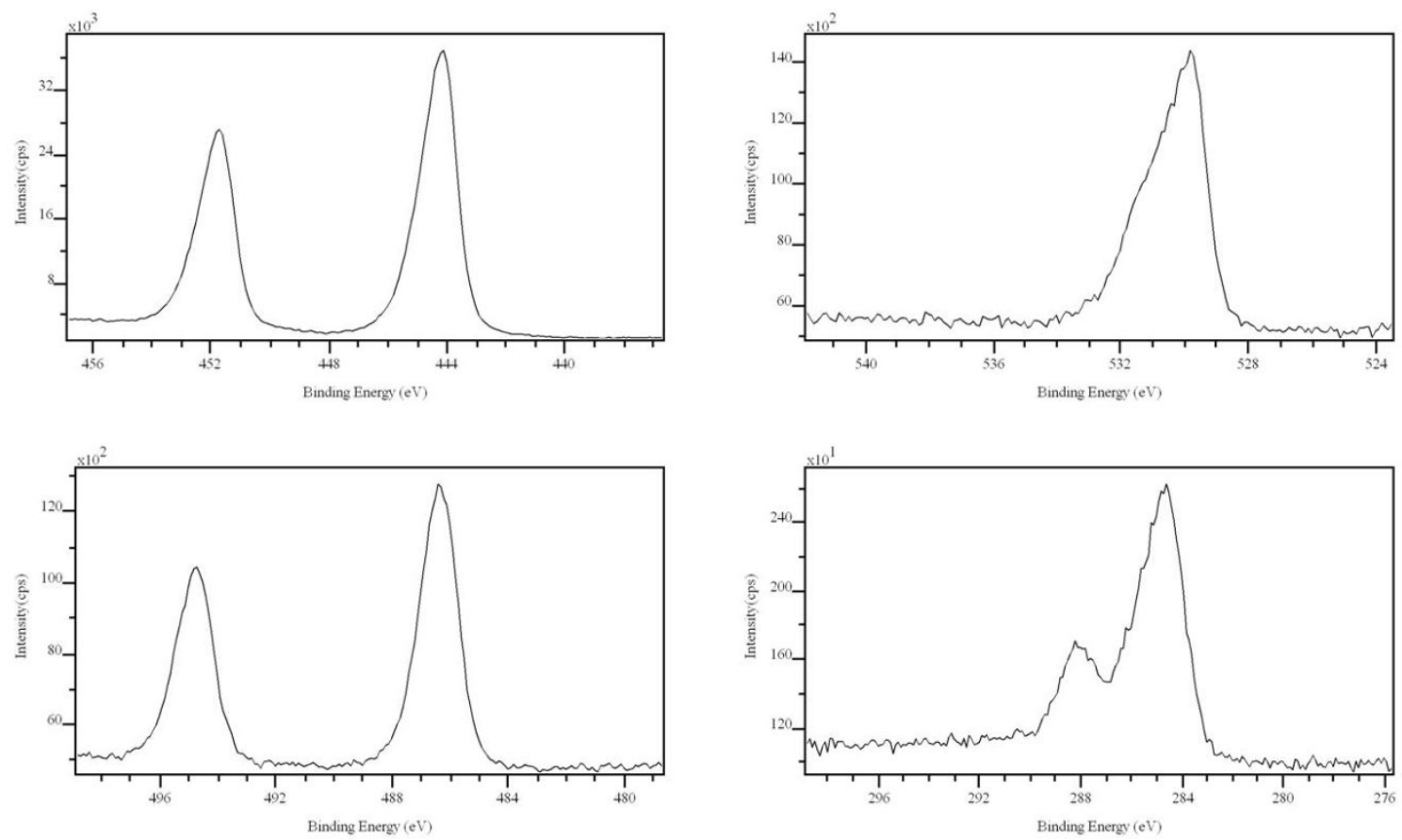

Figure S25. High resolution XPS spectra for nanolTO annealed at $250 \mathrm{C}$. Top Left: In-3d signals; Top Right: O-1s signals; Bottom Left: Sn-3d signals; and Bottom Right: C-1s signals. 

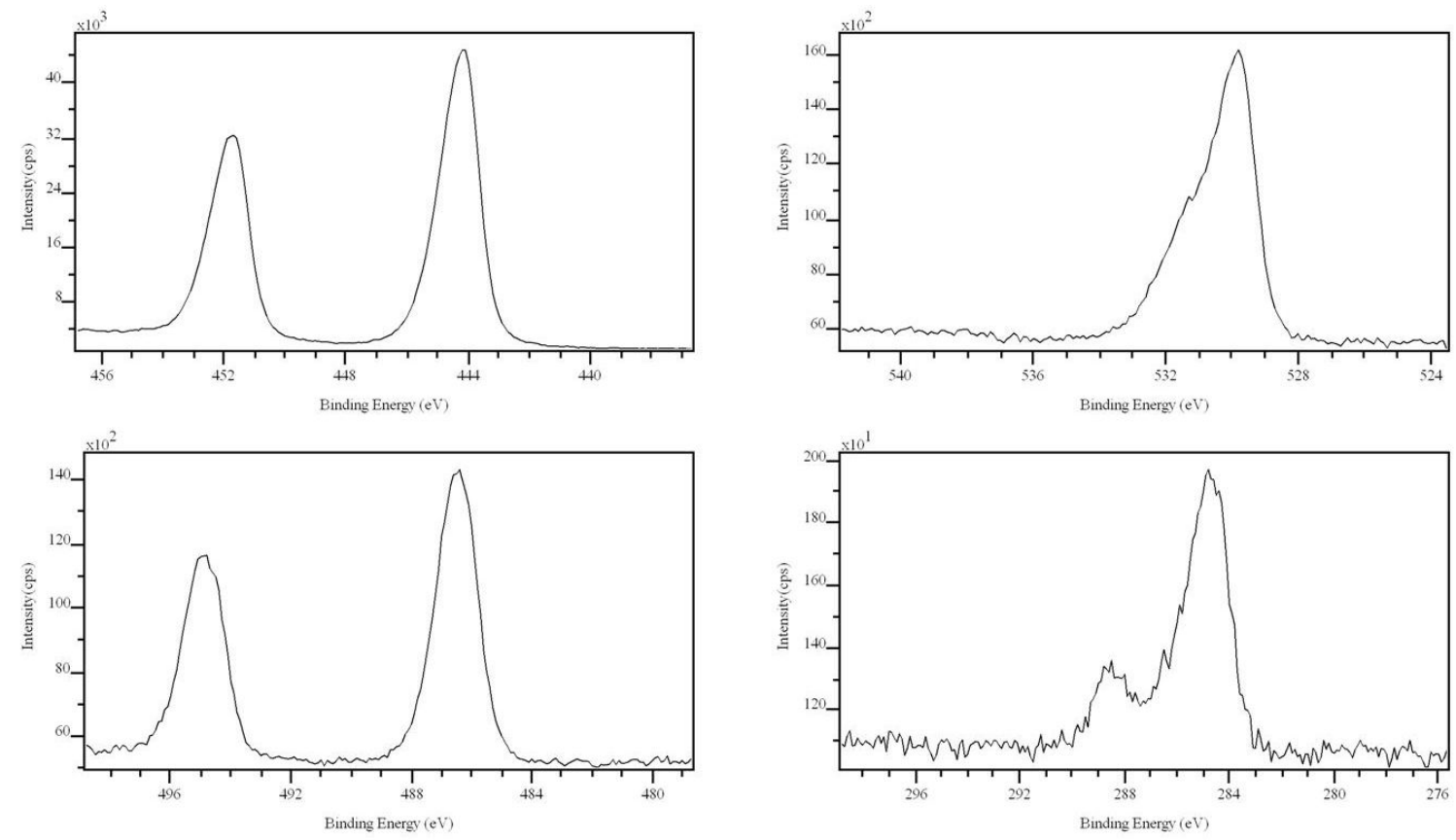

Figure S26. High resolution XPS spectra for nanolTO annealed at $300 \mathrm{C}$. Top Left: In-3d signals; Top Right: O-1s signals; Bottom Left: Sn-3d signals; and Bottom Right: C-1s signals.
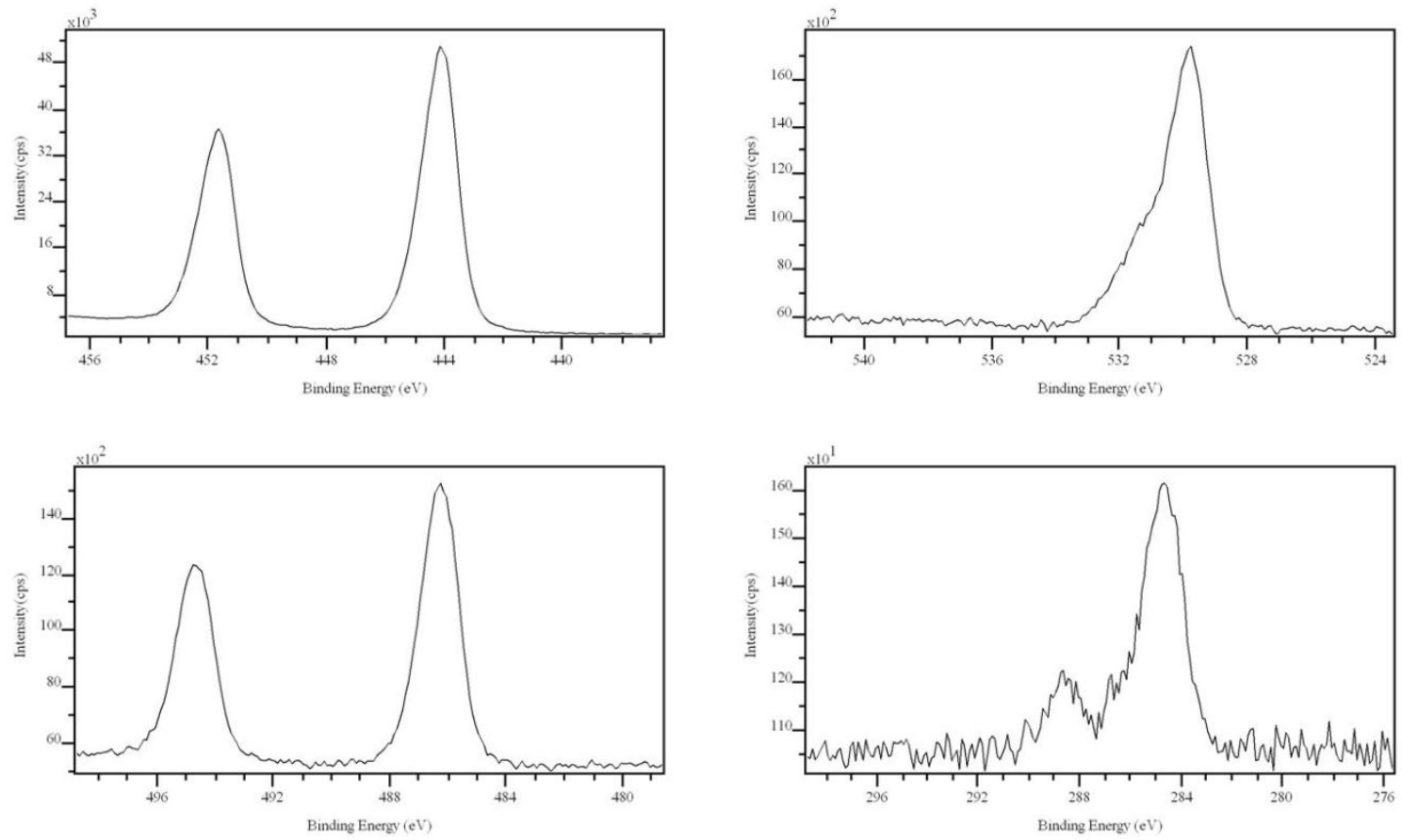

Figure S27. High resolution XPS spectra for nanolTO annealed at $400 \mathrm{C}$. Top Left: In-3d signals; Top Right: O-1s signals; Bottom Left: Sn-3d signals; and Bottom Right: C-1s signals. 

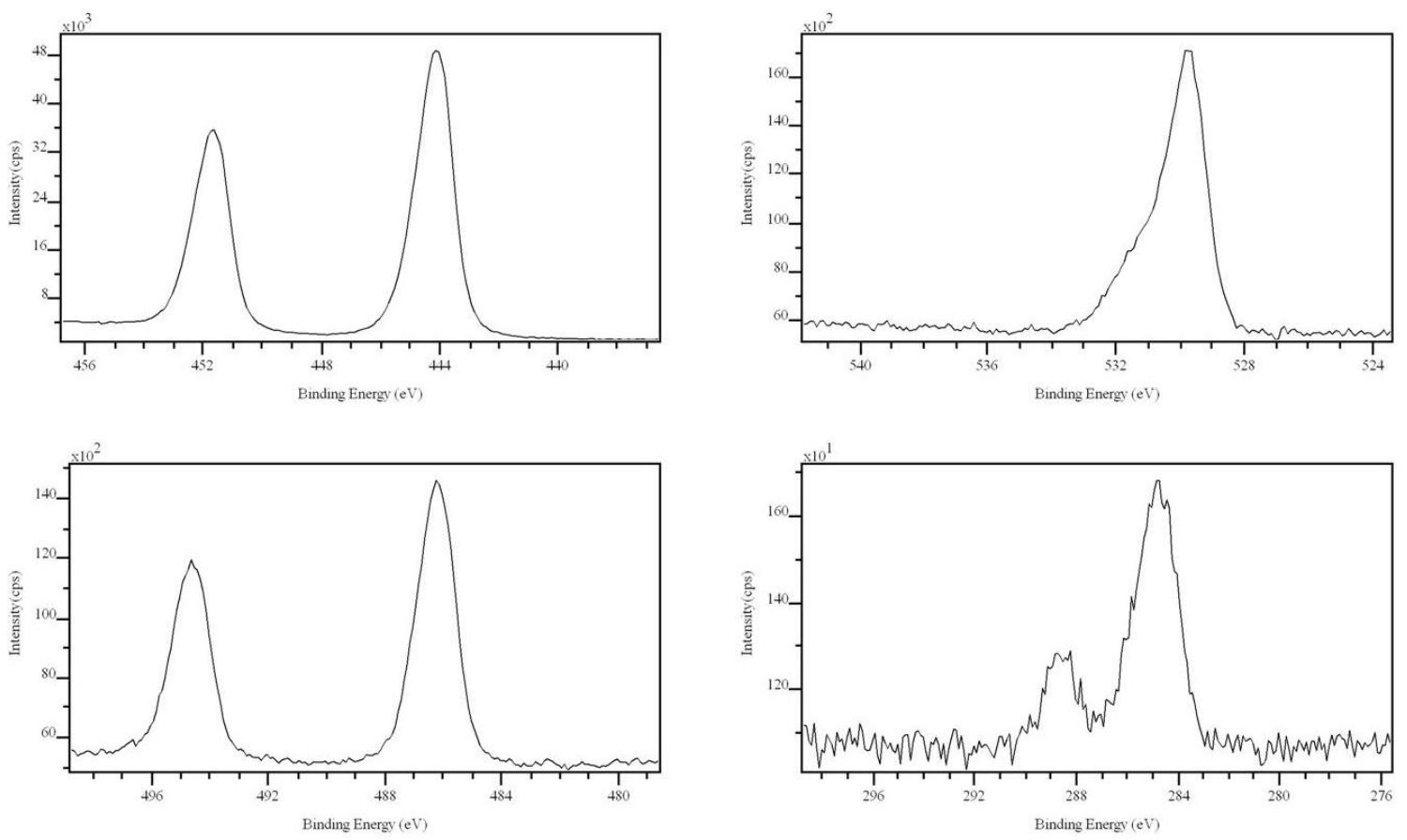

Figure S28. High resolution XPS spectra for nanolTO annealed at $500 \mathrm{C}$. Top Left: In-3d signals; Top Right: O-1s signals; Bottom Left: Sn-3d signals; and Bottom Right: C-1s signals.
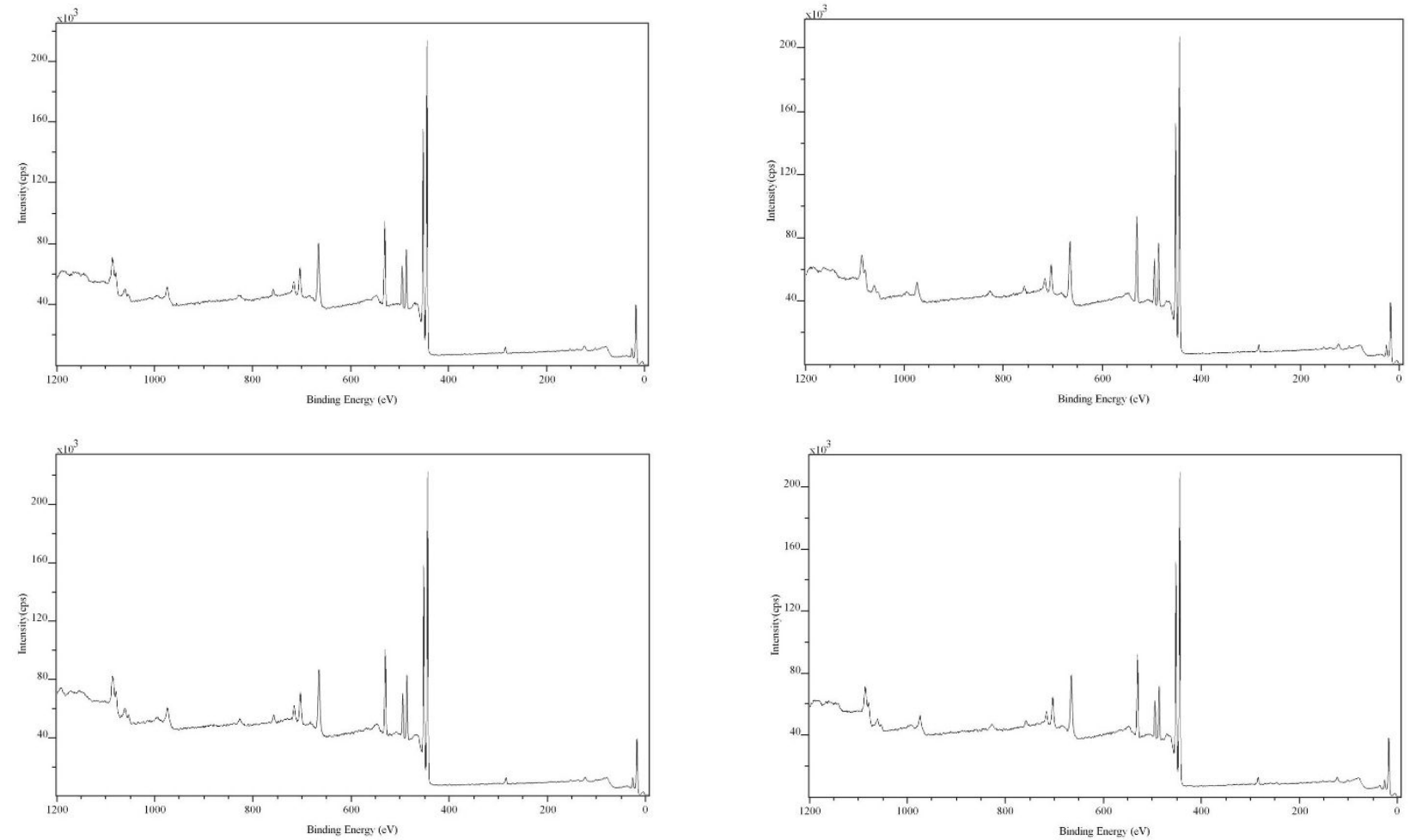

Figure S29. Survey XPS spectra of nanolTO electrodes after: Top Left: soaking in $0.1 \mathrm{M} \mathrm{HNO}_{3}$; Top Right: UV-illumination; Bottom Left: Controlled Potential Electrolysis; Bottom Right: Photoelectrolysis. All procedures lasted $6 \mathrm{~h}$. 

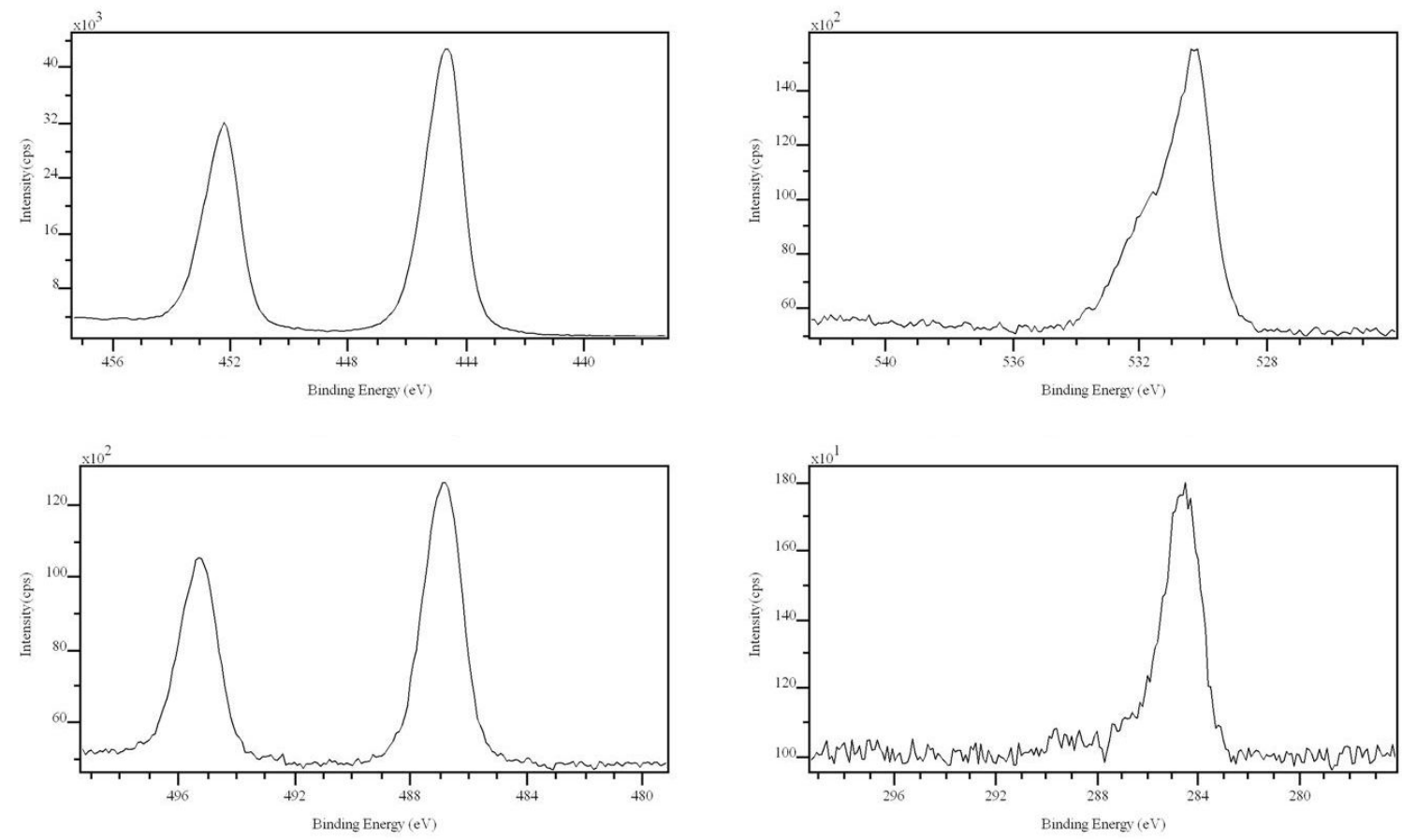

Figure S30. High resolution XPS spectra for nanolTO annealed at $500 \mathrm{C}$ and soaked in $0.1 \mathrm{M}$ $\mathrm{HNO}_{3}$ for $6 \mathrm{~h}$. Top Left: In-3d signals; Top Right: O-1s signals; Bottom Left: Sn-3d signals; and Bottom Right: C-1s signals.
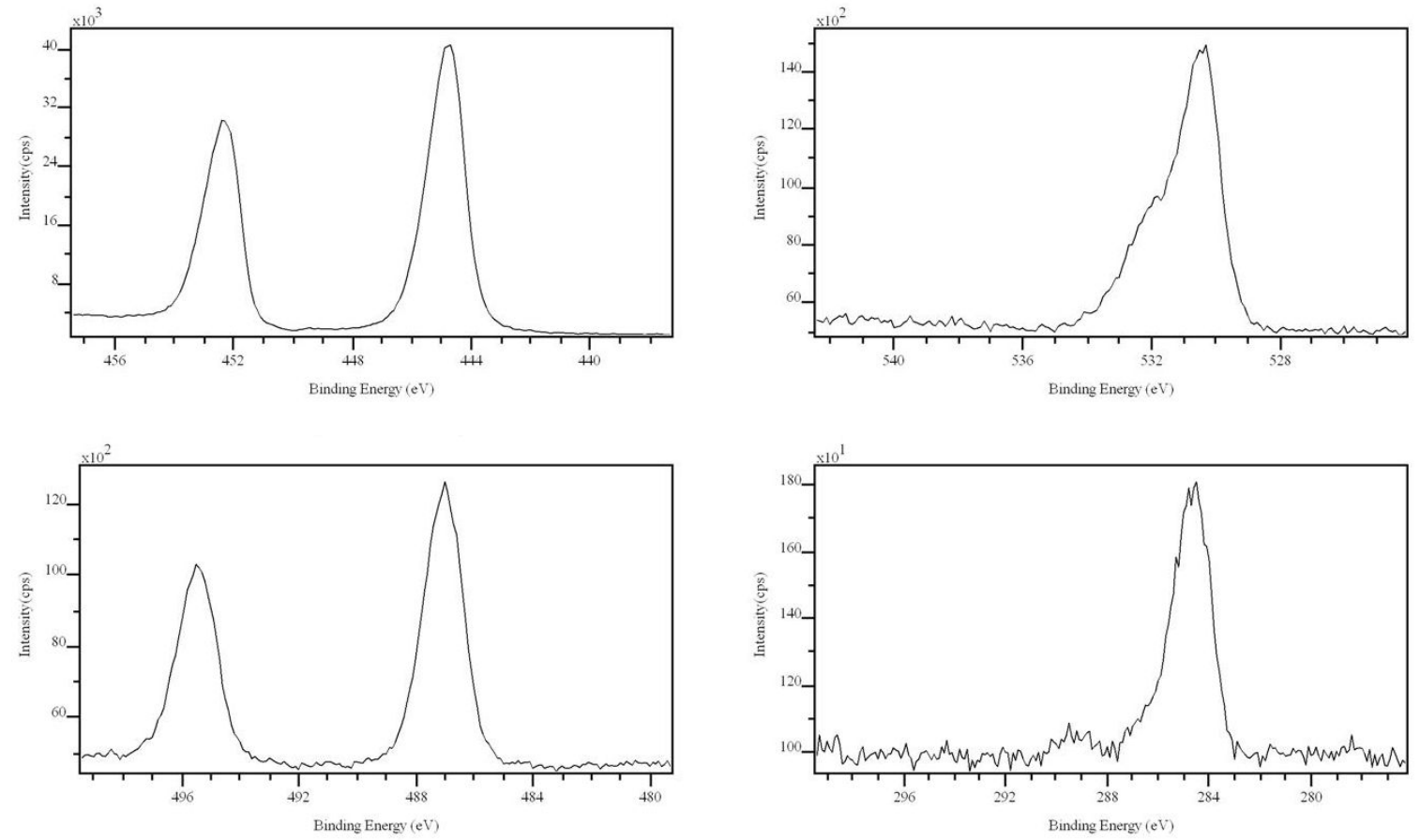

Figure S31. High resolution XPS spectra for nanolTO annealed at $500 \mathrm{C}$ and illuminated at 375 $\mathrm{nm}$ in $0.1 \mathrm{M} \mathrm{HNO}_{3}$ for $6 \mathrm{~h}$. Top Left: In-3d signals; Top Right: O-1s signals; Bottom Left: Sn-3d signals; and Bottom Right: C-1s signals. 

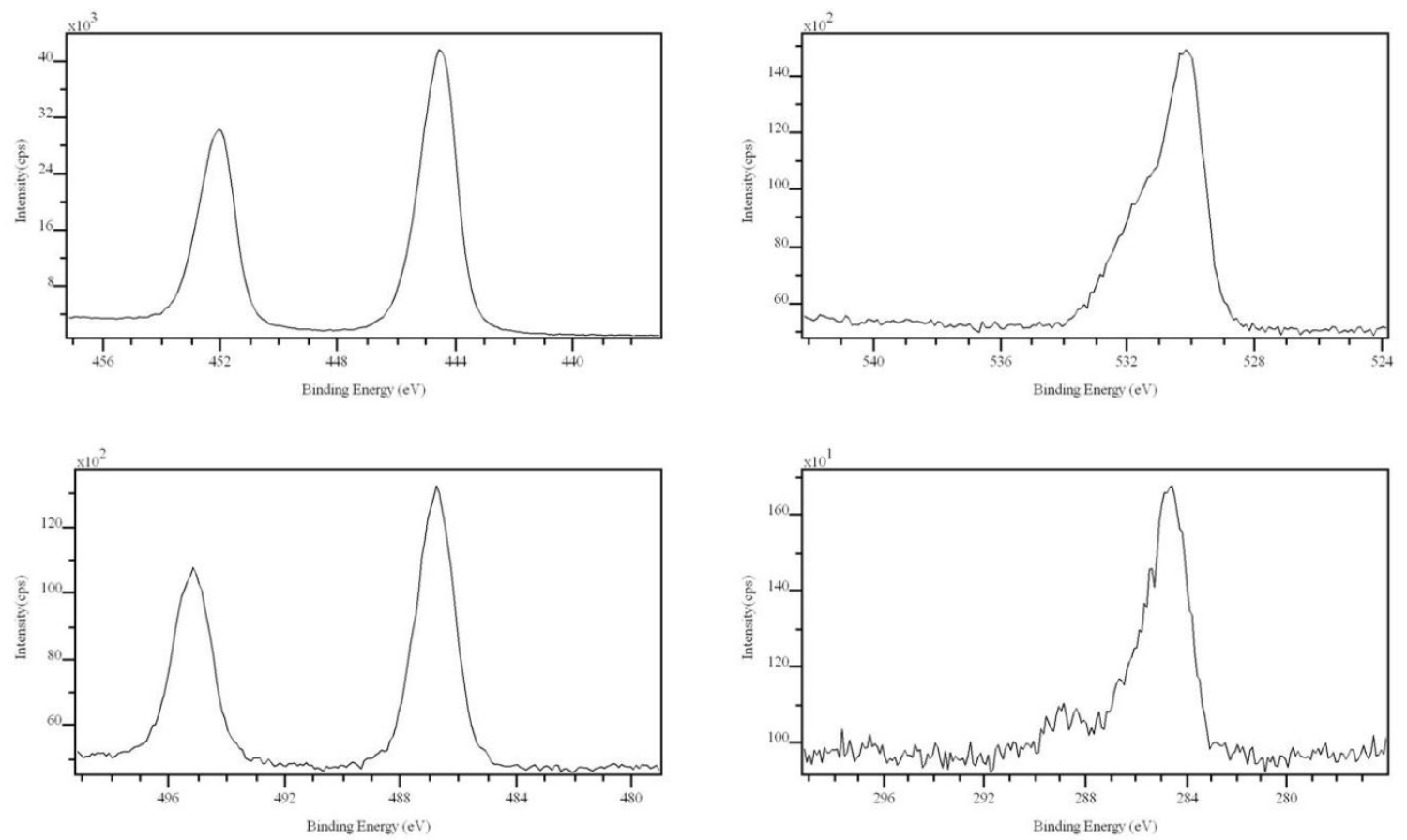

Figure S32. High resolution XPS spectra for nanolTO annealed at $500 \mathrm{C}$ with controlled potential electrolysis at $1.4 \mathrm{~V}$ in $0.1 \mathrm{M} \mathrm{HNO}_{3}$ for $6 \mathrm{~h}$. Top Left: In-3d signals; Top Right: O-1s signals; Bottom Left: Sn-3d signals; and Bottom Right: C-1s signals.
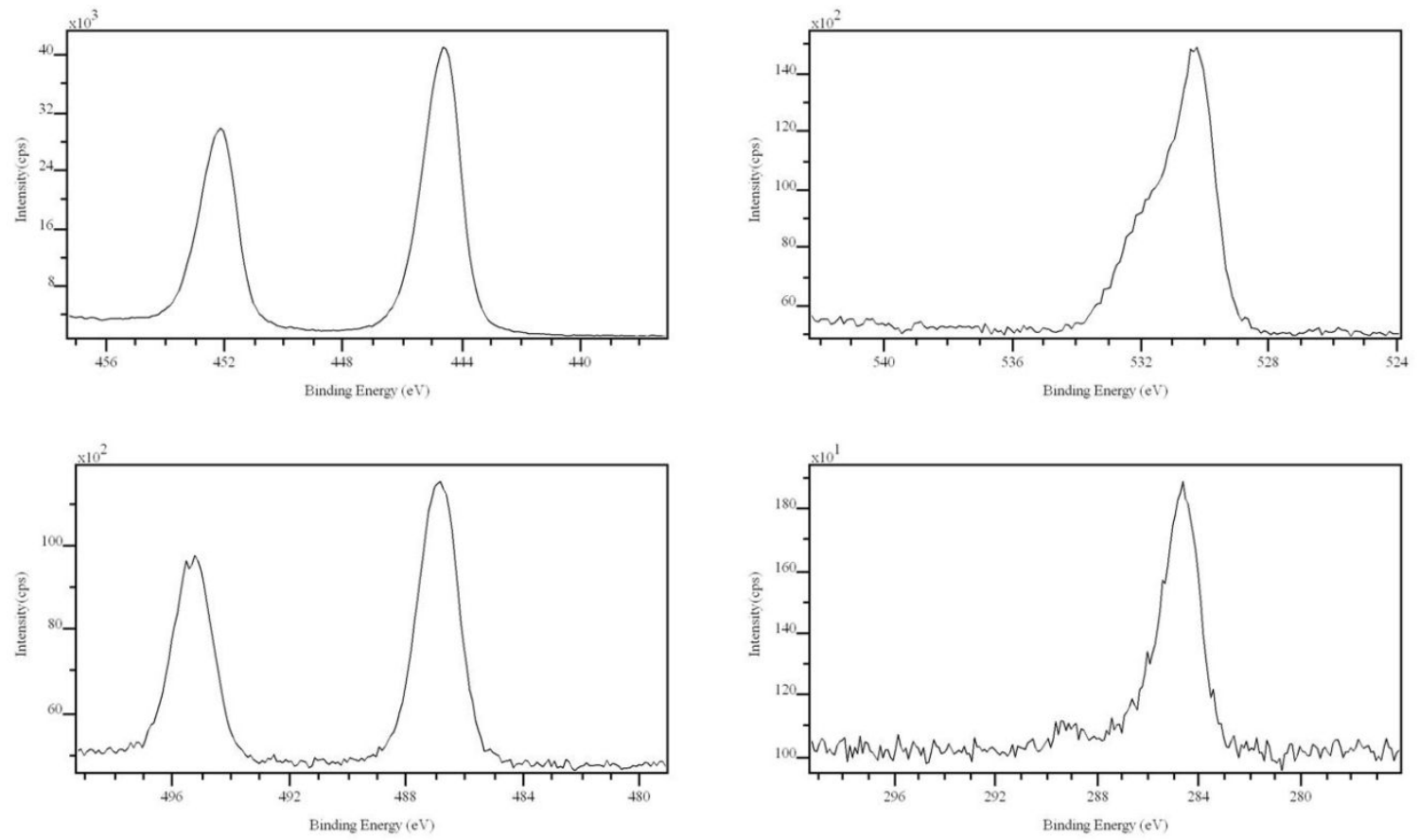

Figure S33. High resolution XPS spectra for nanolTO annealed at $500 \mathrm{C}$ with photoelectrolysis with $375 \mathrm{~nm}$ light illumination and at $1.4 \mathrm{~V}$ in $0.1 \mathrm{M} \mathrm{HNO}_{3}$ for $6 \mathrm{~h}$. Top Left: In-3d signals; Top Right: O-1s signals; Bottom Left: Sn-3d signals; and Bottom Right: C-1s signals. 


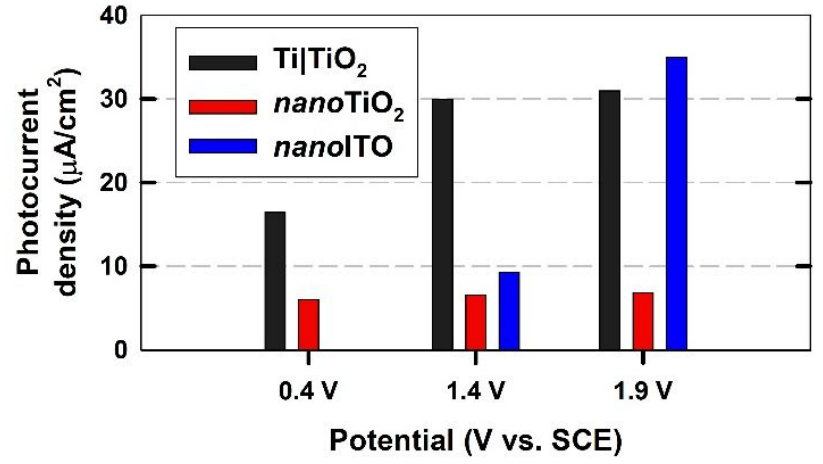

Figure S34. Photocurrent responses in $0.1 \mathrm{M} \mathrm{HClO}_{4}$ for $\mathrm{Ti}^{\mathrm{TiO}} \mathrm{Ti}_{2}$ (Black), nanoTiO 2 (Red), and nanolTO (Blue) at different applied biases using a $300 \mathrm{~nm}$ LED at $0.7 \mathrm{~mW} / \mathrm{cm}^{2}$ illumination.

Table S1. Atomic concentrations of elements present in nanolTO annealed at various temperatures as determined by high resolution XPS (Figures S24 to S28).

\begin{tabular}{rrrrr}
\hline & \multicolumn{4}{c}{ Element } \\
Annealing Temp. $\left({ }^{\circ} \mathrm{C}\right)$ & In & Sn & O & $\mathrm{C}$ \\
\hline 200 & $13.6 \%$ & $2.9 \%$ & $28.8 \%$ & $54.7 \%$ \\
250 & $22.3 \%$ & $4.8 \%$ & $43.2 \%$ & $29.8 \%$ \\
300 & $28.3 \%$ & $5.8 \%$ & $49.9 \%$ & $16.1 \%$ \\
400 & $31.7 \%$ & $6.4 \%$ & $52.2 \%$ & $9.8 \%$ \\
500 & $31.6 \%$ & $6.0 \%$ & $51.1 \%$ & $11.3 \%$ \\
\hline
\end{tabular}

Table S2. Atomic concentrations of elements present in nanolTO annealed at $500{ }^{\circ} \mathrm{C}$ pristine, after soaking in $0.1 \mathrm{M} \mathrm{HNO}_{3}$, photolysis with $375 \mathrm{~nm}$ light, electrolysis at $1.4 \mathrm{~V}$, or photoelectrolysis with $375 \mathrm{~nm}$ light and a $1.4 \mathrm{~V}$ bias. These processes were maintained for $6 \mathrm{~h}$. Data were taken from high resolution XPS data (Figures S30 to S33).

\begin{tabular}{lrrrr}
\hline & \multicolumn{4}{c}{ Element } \\
nanolTO Sample & In & Sn & O & C \\
\hline Pristine & $31.6 \%$ & $6.2 \%$ & $51.6 \%$ & $10.5 \%$ \\
Soaking & $28.9 \%$ & $5.4 \%$ & $53.1 \%$ & $12.6 \%$ \\
Photolysis & $28.6 \%$ & $5.8 \%$ & $52.8 \%$ & $12.8 \%$ \\
Electrolysis & $28.7 \%$ & $5.6 \%$ & $53.3 \%$ & $12.4 \%$ \\
Photoelectrolysis & $28.9 \%$ & $5.2 \%$ & $52.7 \%$ & $13.2 \%$ \\
\hline
\end{tabular}


Table S3. Water oxidation $\mathrm{pH}$ dependence from catalysis onsets in $\mathrm{pH} 1$ and $\mathrm{pH} 7$ in the dark and under UV illumination.

\begin{tabular}{rrr}
\hline $\begin{array}{r}\text { nanolTO annealing } \\
\text { temp. }\left({ }^{\circ} \mathrm{C}\right)\end{array}$ & \multicolumn{2}{c}{ Potential Shift $(\mathrm{mV} / \mathrm{pH})$} \\
200 & 69.8 & Light \\
250 & 0.0 & 63.8 \\
300 & 51.0 & -6.0 \\
400 & 59.5 & 24.5 \\
500 & 31.5 & 18.0 \\
\hline
\end{tabular}

Table S4. OCPs (V vs. SCE) of nanolTO electrodes under various conditions.

\begin{tabular}{rrrrr}
\hline $\begin{array}{r}\text { nanolTO annealing } \\
\text { temp. }\left({ }^{\circ} \mathrm{C}\right)\end{array}$ & Dark & Light & Dark & Light \\
\hline 200 & 0.35 & 0.15 & 0.22 & -0.08 \\
250 & 0.28 & 0.21 & 0.1 & -0.08 \\
300 & 0.12 & 0.15 & 0.07 & 0.05 \\
400 & 0.13 & 0.14 & 0.06 & 0.06 \\
500 & 0.20 & 0.20 & 0.60 & 0.07 \\
\hline
\end{tabular}

\section{References}

1. Gross, M.; Winnacker, A.; Wellmann, P. J., Electrical, optical and morphological properties of nanoparticle indium-tin-oxide layers. Thin Solid Films 2007, 515 (24), 8567-8572. 